March 2016

\title{
Transfer PAYMents AND THE MACROECONOMY: THE EFFECTS OF SOCIAL SECURITY BENEFIT INCREASES, 1952-1991
}

\author{
Christina D. Romer \\ David H. Romer
}

\section{ONLine APPEndix A}

\section{DESCRIPTION OF SOCIAL SECURITY BENEFIT INCREASES, 1952-1991}

This appendix describes Social Security benefit increases from 1952 to $1991{ }^{1}$ We include increases in both the old-age and survivors insurance program (OASI) and the disability insurance program (DI). We also include increases in the Supplemental Security Income (SSI) program, which provides benefits from general revenue for impoverished beneficiaries. We do not include changes in the health insurance component of Social Security (the Medicare program and early precursors).

For the period before 1975, all benefit increases were individually legislated. There were also some legislated changes in the later years of our sample. As described in the text, to identify these we begin with a survey of all legislation related to Social Security produced by the Congressional Research Service. $^{2}$ We use the descriptions in that survey to exclude acts that only expanded coverage or that changed benefits only for future recipients. We also exclude acts that only made small technical corrections or that were never passed. We are left with acts that raised benefit payments for current recipients. ${ }^{3}$ This appendix discusses the nature, motivation, size, timing, and permanence of these benefit increases, as well as the key sources of this information. In addition, we note any tax changes associated with the legislation.

Starting in 1975, Social Security benefits were indexed to inflation. This appendix discusses the size and timing of these automatic increases. During this period, there were also occasional onetime payments not related to legislation but to new interpretations of rules and other factors, which we identify from news reports. We discuss their size, permanence, and timing, along with the sources of the information.

Our focus on the short-run effects of increases in payments to current recipients influences our approach to measuring the size of each increase. We try to identify the aggregate increase in payments to current recipients (at an annual rate) in the first month that the higher payments were received. As a practical matter, with legislated changes this is typically derived from the cost estimates of the legislation in the first period mentioned (which is usually the first full year). For the cost-of-living adjustments, we calculate the aggregate increase by multiplying total Social Security payments (as reported in the NIPA data) in the month before the increase by the official percentage adjustment. For the one-time payments, occasionally the news stories discuss their size, but often they do not. To estimate the size of a payment, we therefore take the increase in the NIPA Social Security series in the month for which our news stories identify a payment.

\footnotetext{
${ }^{1}$ We have also examined the narrative record for 1951 and found no Social Security benefit increases in this year.

${ }^{2}$ Congressional Research Service, 2001, Major Decisions in the House and Senate on Social Security: 1935-2000, https://www.socialsecurity.gov/history/reports/crsleghist3.html.

${ }^{3}$ We also consider extensions of benefits to individuals unlikely to respond by switching from employment to retirement (such as disabled people or stay-at-home spouses).
} 


\section{Social Security Act Amendments of 1952 (enacted July 18, 1952)}

\section{October 1952: \$0.6677 billion permanent benefit increase}

This legislation increased old-age and survivors benefits by roughly $12 \frac{1}{2} 2$ percent. It also provided additional funds to the states for public assistance for impoverished aged, blind, and disabled beneficiaries.

The motivation for the increase was to keep up with the inflation that had occurred during the Korean War. The report of the Senate Finance Committee stated that "The rapid rise in wages and prices during the last few years makes immediate benefit adjustments imperative" (Senate Finance Committee, $82^{\mathrm{d}}$ Congress, $2^{\mathrm{d}}$ Session, Senate Report No. 1806, "Social Security Act Amendments of 1952,” June 23, 1952, p. 2). The 1953 Economic Report of the President also suggested this motivation as well, stating that the Social Security system "has been partially strengthened against the tide of inflation” (p. 123).

The Finance Committee report stated disbursements would occur in the last three months of 1952, so the first higher checks were received in October (Senate Finance Committee, $82^{\mathrm{d}}$ Congress, $2^{\mathrm{d}}$ Session, Senate Report No. 1806, “Social Security Act Amendments of 1952,” June 23, 1952, p. 16). The Social Security Bulletin also said that the new benefits table was applicable to September 1952, and so would be reflected in October checks (Cohen, "Social Security Act Amendments of 1952," September 1952, p. 4). ${ }^{4}$ The increase in Social Security benefits was expected to cost $\$ 400-$ $\$ 450$ million in the first full year of operation (1953) (Senate Finance Committee, Senate Report No. 1806, p. 16). The public assistance provisions cost an additional $\$ 242.7$ million annually (Cohen, “Social Security Act Amendments of 1952," Social Security Bulletin, September 1952, p. 9). Therefore, we identify an increase in benefits of $\$ 667.7$ million (\$425 million-the midpoint of the estimates-plus $\$ 242.7$ million) in October 1952. The Social Security benefit increase was intended to be permanent. The public assistance increase was legislated for two years, with the understanding it would come up for renewal (Cohen, p. 9). Since people quite likely expected the increase to be renewed, we treat the entire benefit rise as permanent.

There were no tax increases included in this legislation. According to the Senate Finance Committee, the rise in earnings over the previous three or four years meant that the trust fund would remain in actuarial balance despite the benefit increase (Senate Finance Committee, $82^{\mathrm{d}}$ Congress, $2^{\mathrm{d}}$ Session, Senate Report No. 1806, “Social Security Act Amendments of 1952,” June 23, 1952, p. 8).

\section{Social Security Amendments of 1954 (enacted September 1, 1954) October 1954: \$0.64 billion permanent benefit increase}

This legislation raised Social Security benefits substantially, extended Social Security taxes and eventual benefits to many people not previously covered (most notably self-employed farmers), and extended the public assistance provisions of the 1952 amendments.

\footnotetext{
${ }^{4}$ The timing convention used in official discussions of Social Security is that if a benefit increase is "applicable" or "effective" for a given month, it is reflected in the checks that are received early in the following month. We therefore date an increase that is effective in a given month as taking place the following month. Social Security disability checks are received very late in the month for which they are effective. Since individuals would have had little time within the month to change their spending in response to such increases in benefits, we again date these increases as occurring in the month after they become effective.
} 
The primary motivation for the benefit increase was again to ensure that benefits kept pace with inflation that had already occurred. The report of the Ways and Means Committee stated: "The level of benefits thus established will represent a realistic floor of protection in line with current price and wage levels" (Ways and Means Committee, 83 ${ }^{\mathrm{d}}$ Congress, $2^{\mathrm{d}}$ Session, House Report No. 1698, "Social Security Amendments of 1954," May 28, 1954, p. 15). The Senate Finance Committee report said the increase was needed "to bring benefits more in line with present-day price and wage levels” (Senate Finance Committee, $83^{\mathrm{d}}$ Congress, $2^{\mathrm{d}}$ Session, Senate Report No. 1987, “Social Security Amendments of 1954,” July 27, 1954, p. 1).

According to the Social Security Bulletin, the benefit increase was effective in September, and so affected checks starting in October 1954 (Cohen, Ball, and Myers, "Social Security Act Amendments of 1954: A Summary and Legislative History," September 1954, p. 3). The same source estimated that in 1955 (the first full year of higher benefits), the cost of Social Security benefits overall would be higher by $\$ 640$ million (p. 14). Because newly eligible workers had to work at least six quarters after 1954 to be fully insured (p. 10), the cost estimate for 1955 shows primarily the cost of the increase in benefits for current beneficiaries, not of the expansion of coverage. The Senate Finance Committee report gave a slightly higher number of around $\$ 700$ million as the cost in 1955 (Senate Finance Committee, 83 ${ }^{\mathrm{d}}$ Congress, $2^{\mathrm{d}}$ Session, Senate Report No. 1987, “Social Security Amendments of 1954," July 27, 1954, p. 32), but we use what appears to be the final number from the Social Security Bulletin. According to the Social Security Bulletin, "Benefit payments are increased for beneficiaries presently on the rolls as well as for those qualifying in the future” (Cohen, Ball, and Myers, p. 7). That is, it was intended to be permanent.

As discussed in Romer and Romer (2009, pp. 30-31), the legislation increased Social Security taxes by $\$ 0.5$ billion in January 1955 to partially pay for the spending increase. ${ }^{5}$

\section{Social Security Amendments of 1956 (enacted August 1, 1956) \\ December 1956: $\$ \mathbf{0 . 4 8 5}$ billion permanent benefit increase August 1957: $\$ \mathbf{\$ 0 . 2 7 8 4}$ billion permanent benefit increase}

These amendments primarily extended benefits to people unlikely to be working. In particular, it allowed widows and mothers with dependent children to receive full retirement benefits at age 62 rather than age 65. (The law also allowed working women and wives to take reduced benefits starting at age 62, but this provision was not expected to account for a significant fraction of the cost, at least initially). The amendments also set up the disability insurance program, which provided cash benefits for people aged 50-65 who had contributed to the Social Security program and who were unable to work because of disability.

The motivation for the act was to increase the economic security provided by the Social Security program. The Ways and Means Committee report said that the changes would "strengthen the old-age and survivors insurance program" (Ways and Means Committee, $84^{\text {th }}$ Congress, $1^{\text {st }}$ Session, House Report No. 1189, “Social Security Amendments of 1955,” July 14, 1955, p. 2). President Eisenhower, in his signing statement, expressed some concern about the expansion of benefits, but was "hopeful that this new law, on the whole, will advance the economic security of the American people" (Eisenhower, "Statement by the President Upon Signing the Social Security

\footnotetext{
${ }^{5}$ Christina D. Romer and David H. Romer, 2009, “A Narrative Analysis of Postwar Tax Changes,” Unpublished paper, University of California, Berkeley, https://www.aeaweb.org/aer/data/june2010/20080421_app.zip.
} 
Amendments of 1956,” August 1, 1956, p. 1). ${ }^{6}$

According to a Senate Finance Committee print, the lower age of benefits for women was payable beginning in November 1956, so it appeared in December 1956 checks (Senate Finance Committee, "Old-Age, Survivors, and Disability Insurance and Public Assistance: Showing Changes Made by the Social Security Amendments of 1956," 1956, p. 12). ${ }^{7}$ The Social Security Bulletin indicates that the disability payments first showed up in checks in August 1957 (Myers, "Old-Age and Survivors Insurance: Financing Basis and Policy Under 1956 Amendments," September 1956, Table 3, p. 18). The new disability benefits were estimated to cost $\$ 116$ million in 1957 (Myers, Table 6, p. 20). Since this amount was for only five months, this implies an increase in benefits at an annual rate of $\$ 278.4$ million. The total increase in benefits from the amendment in 1957 was $\$ 601$ million (Myers, p. 18). Subtracting off the \$116 million due to disability payments leaves \$485 million for the benefit increases beginning in December 1956 (which, since it is for 1957, reflects an annual rate). All of the increases were intended to be permanent.

The legislation also increased the Social Security tax rate effective January 1, 1957 to pay for the benefit increases. The revenue effect was $\$ 0.9$ billion at annual rate (Romer and Romer, 2009, p. 32).

\section{Social Security Amendments of 1958 (enacted August 28, 1958) \\ October 1958: $\$ \mathbf{\$ 0 . 2}$ billion permanent benefit increase February 1959: $\$ 0.709$ billion permanent benefit increase}

This act increased benefit amounts by about 7 percent for both retired and disabled workers. It also provided dependents' benefits for people receiving disability payments.

The primary motivation for the increase was to keep up with inflation. The Ways and Means Committee report said: "The old-age and survivors insurance benefit structure ... [has] not been revised by the Congress since 1954. Since that date there have been significant increases in wages and prices .... In the light of these developments, it is imperative that the Congress take prompt action to assure that the program be kept both effective and actuarially sound" (Ways and Means Committee, $85^{\text {th }}$ Congress, $2^{\mathrm{d}}$ Session, House Report No. 2288, "Social Security Amendments of 1958,” July 28, 1958, pp. 1-2). President Eisenhower seconded this motivation in his signing statement, saying: "The increases in benefits and in the tax base are desirable in the light of changes in the economy since these provisions were last amended in 1954" (Eisenhower, "Statement by the President Upon Signing the Social Security Amendments,” August 29, 1958, p. 1).

According to the Social Security Bulletin, the higher benefit rates became effective in January 1959, and so first were reflected in checks for February 1959 (Schottland, "Social Security Amendments of 1958: A Summary and Legislative History," October 1958, p. 4). Disbursements were expected to be about \$650 million higher in 1959 than under previous law (Myers, "Old-Age, Survivors, and Disability Insurance: Financing Basis and Policy Under the 1958 Amendments,”

\footnotetext{
${ }^{6}$ All presidential speeches cited in the paper are available from John T. Woolley and Gerhard Peters, The American Presidency Project, www.presidency.ucsb.edu.

${ }^{7}$ The act also included expanded benefit payments for disabled children, which were payable beginning in January 1957. Because the Social Security Bulletin shows that these benefits were small, we include them in the December 1956 figure (Myers, "Old-Age and Survivors Insurance: Financing Basis and Policy Under 1956 Amendments," September 1956, Table 3, p. 18).
} 
October 1958, p. 19). Since the higher benefits were paid for only eleven months in that year, the increase at an annual rate was $\$ 709$ million. The new dependents' benefits for disabled workers were payable in September 1958, so the first checks arrived in October 1958 (Schottland, p. 7). The Social Security Bulletin stated that disbursements in 1959, the first full year under the new dependents' benefits, would be $\$ 200$ million (Myers, p. 20). All benefit increases in the law were permanent.

The Social Security Amendments of 1958 also legislated a tax increase of $\$ 1.1$ billion beginning in January 1959 and another of \$1.9 billion in January 1960. Though both increases were designed to offset the new spending in the legislation, the second occurred more than twelve months after the spending increase. Therefore, following our usual procedures, the first is classified as spending-driven; the second as deficit-driven (Romer and Romer, 2009, pp. 33-34).

\section{Social Security Amendments of 1960 (enacted September 13, 1960)}

\section{December 1960: \$0.2 billion permanent benefit increase} January 1961: \$0.25 billion permanent benefit increase

One of the main changes contained in this law is not something we consider in this paper: the creation of a limited program to help pay for health care for the needy aged. The act did, however, also contain some benefit increases. It expanded disability benefits to disabled people younger than age 50. It also increased survivor benefits for children.

Most of the discussion of motivation focused on the high and rising cost of health care, and the problems faced by the elderly in paying for insurance and care (Senate Finance Committee, $86^{\text {th }}$ Congress, $2^{\mathrm{d}}$ Session, Senate Report No. 1856, “Social Security Amendments of 1960," August 19, 1960, pp. 1-2). The motivation for the non-health related portions appears to have been a desire to increase the insurance component of the program. According to the Social Security Bulletin, the benefit extensions were recommended by the administration (Mitchell, "Social Security Legislation in the Eighty-sixth Congress,” November 1960, pp. 16-17).

The increase in disability benefits was payable for November 1960, and so was reflected in December checks (Mitchell, "Social Security Legislation in the Eighty-sixth Congress," Social Security Bulletin, November 1960, p. 18). According to another article in the Social Security Bulletin, the cost of the new benefits in their first full year (1961) was estimated to be \$200 million (Myers, "Old-Age, Survivors, and Disability Insurance: Financing Basis and Policy Under the 1960 Amendments," November 1960, p. 35). The increase in survivors' benefits was payable in December 1960, and so affected checks in January 1961 (Mitchell, p. 20). Disbursements were estimated to be $\$ 250$ million more in 1961 than they would have been under previous law (Myers, p. 34). The increases were all permanent.

The law contained no revenue provisions. Under intermediate cost estimates, it was estimated that the trust fund remained actuarially sound with the benefit increase (Myers, "Old-Age, Survivors, and Disability Insurance: Financing Basis and Policy Under the 1960 Amendments," Social Security Bulletin, November 1960, p. 36). The health care provisions were paid for out of general revenues (Mitchell, "Social Security Legislation in the Eighty-sixth Congress," Social Security Bulletin, November 1960, p. 14). 


\section{Social Security Amendments of 1961 (enacted June 30, 1961)}

The Social Security Amendments of 1961 raised benefits and changed the Social Security program in important ways. In particular, it raised minimum benefits for retirees and disabled beneficiaries substantially, and raised benefits to widows and widowers by 10 percent. It also allowed men to retire at age 62 with an actuarially fair reduction in benefits.

This act is the one permanent change in Social Security benefits whose timing was explicitly motivated by the weak state of the economy. President Kennedy outlined the increase as part of his overall strategy to end the recession and encourage growth. He said: "I recommend that Congress enact five improvements in benefits, to become effective April 1. ... Besides meeting pressing social needs, the additional flow of purchasing power will be a desirable economic stimulus at the present time. Early enactment will serve this end" (Kennedy, "Special Message to the Congress: Program for Economic Recovery and Growth,” February 2, 1961, p. 5). The 1962 Economic Report of the President was even more explicit that the timing was deliberately countercyclical. It said: "While transfer programs - like any Federal outlays - ought to stand on their merits, the precise timing of worthwhile new programs properly depends on economic conditions. The objectives of economic stabilization in 1961 argued strongly for speeding the introduction of programs like improvements in social security, scheduled to be adopted later" (p. 83). The Ways and Means Committee emphasized that "Under the improvements recommended in your committee's bill, additional purchasing power will be placed in the hands of people who very much need it" (Ways and Means Committee, $87^{\text {th }}$ Congress, $1^{\text {st }}$ Session, House Report No. 216, "Social Security Amendments of 1961," April 7, 1961, p. 3). Because the timing of the increase appears to be correlated by design with the state of the economy, we exclude this observation from our analysis.

For completeness, however, it is useful to describe the other aspects of the benefit increase. According to the Social Security Bulletin, the benefit increases were effective August 1961 and so were reflected in the checks received in September (Cohen and Mitchell, "Social Security Amendments of 1961: Summary and Legislative History," September 1961, p. 3). The Social Security Bulletin gives two estimates of the aggregate size of the increase. In one article, it says new or increased benefits of $\$ 815$ million would be paid in the first 12 months (Cohen and Mitchell, p. 4). In another, it gives an estimate of \$310 million for the last four months of 1961 (implying an annual rate of $\$ 930$ million) and "about $\$ 900$ million higher than under the previous law" for 1962 (Myers, "Old-Age, Survivors, and Disability Insurance: Financing Basis and Policy Under the 1961 Amendments," Social Security Bulletin, September 1961, p. 17). \$900 million seems a reasonable middle-ground estimate.

If we were including this episode in the analysis, it would be important to consider that about \$440 million was to be paid to early retirees (Cohen and Mitchell, "Social Security Amendments of 1961: Summary and Legislative History,” Social Security Bulletin, September 1961, p. 4). Since most of these early retirees presumably would have been working previously, this portion of the benefit increase likely did not constitute an increase in personal income.

There were two tax increases included in the legislation. Social Security tax rates were increased in both January 1962 and January 1963. The earlier increase was relatively small (\$0.4 billion), while the later increase was more substantial (\$2 billion). Because the 1963 increase was more than twelve months after the related benefit increase, we classified that increase as being for deficit reduction (Romer and Romer, 2009, pp. 35-36). 
Social Security Amendments of 1965 (enacted July 30, 1965)

\section{September 1965: $\$ 2.32$ billion permanent benefit increase $\$ 10.62$ billion one-time payment \\ January 1966: $\quad \$ 0.2$ billion permanent benefit increase}

The main component of the Social Security Amendment of 1965 was the creation of the Medicare program. It also included a 7 percent increase in Old-Age, Survivors, and Disability Insurance (OASDI) benefits, and a number of smaller changes in benefits for particular groups (such as eligible children aged 18-21 attending school).

The main motivation for the act was to provide greater security to the elderly by establishing a mandatory health insurance program. The problems of rising costs and lack of insurance had been discussed frequently in the 1950s and early 1960s (Cohen and Ball, "Social Security Amendments of 1965: Summary and Legislative History," Social Security Bulletin, September 1965, pp. 3-4), and a limited health benefit program for the aged had been created by the 1960 Social Security amendments. President Kennedy proposed what became the Medicare program in early 1963. He said: "A proud and resourceful nation can no longer ask its older people to live in constant fear of a serious illness for which adequate funds are not available" (Kennedy, "Special Message to the Congress on the Needs of the Nation's Senior Citizens,” February 21, 1963, p. 3). The Ways and Means Committee report gave a very similar motivation for the action (Ways and Means Committee, $89^{\text {th }}$ Congress, $1^{\text {st }}$ Session, House Report No. 213, “Social Security Amendments of 1965," March 29, 1965, pp. 20-21).

The motivation for the benefit increase part of the bill was more prosaic: a need to keep up with inflation and raise standards of living. The Ways and Means Committee report stated: "The last general benefit increase was ... payable for January 1959. Since that date there have been changes in the wages, prices, and other aspects of the economy. ... [T] percent increase and the hospital insurance benefits will be to provide a substantial improvement in levels of living” (Ways and Means Committee, $89^{\text {th }}$ Congress, $1^{\text {st }}$ Session, House Report No. 213, "Social Security Amendments of 1965," March 29, 1965, p. 84).

President Johnson, in his Budget Message, said that the benefit increase and hospital insurance program were part of "an overall fiscal policy designed to maintain our steady economic expansion" (Johnson, “Annual Budget Message to the Congress, Fiscal Year 1966,” January 25, 1965, p. 1). Though President Johnson talked about the fact that "our economy is still producing at a level well below its potential" (p. 1), it is clear the 1965 act was not countercyclical in any conventional sense. The 1965 Economic Report of the President emphasized that conditions were "excellent" (p. 3); the Administration just believed "continued rapid expansion of output is called for in 1965” (p. 98).

The two largest components of the benefits increase, the 7 percent increase to OASDI and the continuation of children's benefits to age 21, were made retroactive to January 1965 . According to the 1966 Economic Report of the President, "The retroactive portion of increased benefits, amounting to $\$ 885$ million, was disbursed in September” (p. 52). We therefore identify a one-time payment at an annual rate of $\$ 10.62$ billion in September 1965. The Social Security Bulletin projected that additional cash payments because of the act would be $\$ 2.32$ billion in 1966 (Cohen and Ball, "Social Security Amendments of 1965: Summary and Legislative History," September 1965, p. 16). We take this as a measure of the permanent increase in benefits (at an annual rate), which appeared in checks in September 1965. 
In addition to the temporary and permanent increases in benefits in September 1965, the act also raised taxes. There was a \$6 billion spending-driven tax increase in January 1966 and another \$1.5 billion spending-driven increase in January 1967 (Romer and Romer, 2009, pp. 41-42).

\section{Tax Adjustment Act of 1966 (enacted March 15, 1966) \\ November 1966: $\$ 0.115$ billion permanent benefit increase}

The main feature of the Tax Adjustment Act of 1966 was a temporary tax increase "designed to reduce inflationary economic pressures generated by the increased military and economic expenditures for Vietnam in an economy rapidly approaching full employment" (Joint Committee on Internal Revenue Taxation, "Summary of the Tax Adjustment Act of 1966," March 29, 1966, p. 1). But it also included a small increase in Social Security benefits for older seniors. The act granted Social Security benefits to those 72 years of age or older, even if they had no quarters of qualifying employment. Because the benefit increase was added late in the legislative process, it was not discussed in the Committee reports. However, President Johnson, in his signing statement, said the motivation for this provision was "bringing economic security to older citizens" (Johnson, “Statement by the President Upon Signing the Tax Adjustment Act of 1966," March 15, 1966, p. 1). Because such older workers were unlikely to still be in the labor force, we include this extension of benefits in our sample.

According to the summary of the act by the Joint Committee on Internal Revenue Taxation, the new benefits were payable for October 1966, so the checks would reach households in November (Joint Committee on Internal Revenue Taxation, "Summary of the Tax Adjustment Act of 1966," March 29, 1966, p. 2). Payments in the first full fiscal year under the law (1968) were estimated to be \$115 million (p. 26). The benefit increase was legislated to be permanent.

The Tax Adjustment Act of 1966 included an excise tax increase of \$0.9 billion starting in April 1966. Since it was designed to counteract the impact of a long-run cut in excise taxes on telephones and automobiles, we classify it as being for long-run purposes (Romer and Romer, 2009, pp. 42-43). The tax increase was explicitly temporary. There were no changes in Social Security taxes associated with the benefit increase.

\section{Social Security Amendments of 1967 (enacted January 2, 1968) March 1968: \$3.5 billion permanent benefit increase}

The Social Security Amendments of 1967 provided a 13 percent increase in old-age, survivors, and disability insurance benefits. It also included substantial increases in the public assistance and child welfare provisions of the Social Security Act.

The motivation for the increase appears to have been to increase standards of living for the elderly and to reduce poverty. In 1966, President Johnson commissioned a study "of ways and means of making social security benefits more adequate" (Cohen and Ball, "Social Security Amendments of 1967: Summary and Legislative History,” Social Security Bulletin, February 1968, p. 4). In a speech to Congress, Johnson said: "I propose Social Security legislation which will bring the greatest improvement in living standards for the elderly since the Act was passed in 1935" (Johnson, "Special Message to the Congress Proposing Programs for Older Americans," January 23, 1967, p. 2). And in his signing statement, he said that because of the increase in benefits, " 1 million 
more people will be lifted above the poverty line" (Johnson, "Statement by the President Upon Signing the Social Security Amendments and Upon Appointing a Commission To Study the Nation's Welfare Programs,” January 2, 1968, p. 1). The Congressional reports did not give much additional information about motivation. Instead, they emphasized that Congress was following the Administration's recommendations (see, for example, Senate Finance Committee, $90^{\text {th }}$ Congress, $1^{\text {st }}$ Session, Senate Report No. 744, “Social Security Amendments of 1967,” November 14, 1967, p. 7).

A summary of the amendments said that the increased benefits were "first payable for the month of February 1968 and will be reflected in checks received early in March" (Senate Finance Committee and Ways and Means Committee, $90^{\text {th }}$ Congress, $1^{\text {st }}$ Session, "Summary of Social Security Amendments of 1967," December 1967, p. 1). The same summary gave a dollar value of the benefit increase of more than $\$ 3$ billion in the first twelve months (p. 1). Other miscellaneous benefit increases (such as additional survivors' benefits for children) bring the total somewhat higher. The Social Security Bulletin gave a total for the increase in disbursements under the new law of \$2.9 billion in calendar year 1968 (Myers and Bayo, "Financing Basis of Old-Age, Survivors, and Disability Insurance and Health Insurance Under the 1967 Amendments,” February 1968, p. 25). Since this was for only 10 months, it suggests an annual rate increase of approximately $\$ 3.5$ billion. The benefit increase was permanent.

The Social Security Amendments of 1967 also raised taxes substantially in three steps. There were increases of \$2 billion in January 1968, \$3 billion in January 1969, and \$3.6 billion in January 1971. The first two are classified as spending-driven because they occurred within a year of the related spending increases; the third is classified as deficit-driven (Romer and Romer, 2009, pp. 4748).

\section{Tax Reform Act of 1969 (enacted December 30, 1969) \\ April 1970: $\$ 4.116$ billion permanent benefit increase $\$ 8.232$ billion one-time payment}

The Tax Reform Act of 1969 primarily reduced taxes and reformed the tax code. But it also included a 15 percent increase in Social Security benefits.

President Johnson recommended an increase in his lame-duck Budget Message in January 1969. He gave as the motivation, "To enable social security beneficiaries to share more equitably in the productivity of our Nation” (Johnson, "Annual Budget Message to the Congress, Fiscal Year 1970,” January 15, 1969, p. 11). President Nixon, in an address to Congress nine months later, stressed past inflation as the primary motivation for the increase: "The impact of an inflation now in its fourth year has undermined the value of every Social Security check and requires that we once again increase the benefits to help those among the most severely victimized by the rising cost of living” (Nixon, "Special Message to the Congress on Social Security,” September 25, 1969, p. 1). He went even further and advocated automatic indexing (also p. 1), but that provision was not included in this legislation. The Ways and Means Committee report did not give a clear indication of its motivation, saying only that extensive hearings had revealed "a pressing and urgent need for an across-the-board increase in the social security payments" (Ways and Means Committee, 91 ${ }^{\text {st }}$ Congress, $1^{\text {st }}$ Session, House Report No. 91-700, “Social Security Amendments of 1969," December 5, 1969, p. 1).

None of the sources suggest that the increase was motivated by the state of the economy. 
President Nixon in his signing statement suggested that the increase in Social Security benefits was slightly larger than he thought necessary. He also said that it was irresponsible to be increasing the budget deficit (as this bill did) "at a time and in a way that raises prices" (Nixon, "Statement on Signing the Tax Reform Act of 1969,” December 30, 1969, p. 1).

The Social Security Bulletin made clear that the higher benefits first appeared in the checks delivered in early April ("Notes and Brief Reports: Effect of OASDI Benefit Increases," June 1970, p. 17). It also reported that the new law raised benefits relative to previous law by about $\$ 343$ million per month (p. 17). Therefore we date a permanent increase in benefits in April of \$4.116 billion at an annual rate. Both the Ways and Means Committee report and the Economic Report of the President for 1970 said that the higher benefits were retroactive to January 1970 (Ways and Means Committee, 91 ${ }^{\text {st }}$ Congress, $1^{\text {st }}$ Session, House Report No. 91-700, "Social Security Amendments of 1969," December 5, 1969, p. 2; and 1970 Economic Report of the President, p. 62). Since the April check was for benefits payable in March, this leaves 2 months of retroactive benefits. Using the \$343 million per month yields a one-time payment (which also came in April) of \$686 million, or $\$ 8.232$ billion at an annual rate. This payment was clearly temporary. ${ }^{8}$

The Tax Reform Act of 1969 included a number of tax cuts. We classify some of them as countercyclical ( $-\$ 6.7$ billion in January $1970 ;-\$ 4.7$ billion in January 1971 ; and $-\$ 1.1$ billion in January 1972), and some as being for long-run purposes ( $-\$ 1.0$ billion in January 1971 and $-\$ 1.0$ billion in January 1972). There was no increase in payroll taxes to pay for the substantial benefit increase (Romer and Romer, 2009, pp. 49-53). The Ways and Means Committee report explained that "a recent revision in the long-range cost estimates of the system showed for the old-age, survivors, and disability programs an actuarial surplus ... sufficient to meet the cost of a 15-percent benefit increase" (Ways and Means Committee, $91^{\text {st }}$ Congress, $1^{\text {st }}$ Session, House Report No. 91-700, “Social Security Amendments of 1969,” December 5, 1969, pp. 1-2).

\section{Public Law 92-5: Public Debt; Social Security Benefit Increase (enacted March 17, 1971) June 1971: \$3.443 billion permanent benefit increase $\$ 13.776$ billion one-time payment}

Public Law 92-5 was originally a bill to increase the ceiling on the national debt. Very late in the legislative process, a 10 percent Social Security benefit increase was added. This increase, along with other major revisions to the Social Security and Medicare programs, had been debated as the Social Security Amendments of 1970, which never passed the Senate.

Congressional documents provide remarkably little information about the motivation for the benefit increase. However, given that the increase was a response to President Nixon's proposal, it is safe to assume that the President's motivation was central. Nixon argued forcefully for indexing Social Security benefits. In response to the House's passage of the Social Security Amendments of 1970, which included this provision, he issued a statement that said: "People receiving social security benefits have been among those hardest hit by a 5-year inflation of their cost of living. This reform would give them the peace of mind that comes from the certainty that the purchasing power

\footnotetext{
${ }^{8}$ The 1970 Economic Report of the President gave a figure of $\$ 4.4$ billion for the permanent increase and $\$ 2.8$ billion for the one-time payment (p. 62). While the $\$ 4.4$ figure is not much different from the $\$ 4.1$ billion we obtain from the Social Security Bulletin, the $\$ 2.8$ billion is wildly different. At an annual rate, that would be nearly $\$ 34$ billion, which is implausibly large. For example, it is vastly different from the rise in personal income in April 1970. For this reason, we assume it is an error of some sort and use the number from the Social Security Bulletin.
} 
of their benefit checks will not be eroded" (Nixon, "Statement About Passage by the House of the Social Security Amendments of 1970,” May 22, 1970, p. 1). Thus, clearly a prime motivation was keeping up with inflation. President Nixon was disappointed that the 1971 measure did not include the cost-of-living escalator. But he said he signed it because "This measure provides some of the relief which the 26 million social security recipients have urgently needed for a long time" (Nixon, "Statement on Signing Bill Increasing Social Security Benefits,” March 17, 1971, p. 1).

The benefit increase was made retroactive to January 1971. The Social Security Bulletin said, "The payment for May, mailed early in June, will be the first to reflect the 10-percent increase in monthly benefits, and a separate payment sent later in June will cover the retroactive amount of the increase for the months of January through April" ("Social Security in Review: Social Security Act Amended," May 1971, p. 1). A committee print from the Ways and Means Committee said that the cost of the permanent 10 percent benefit increase in calendar year 1971 would be $\$ 3.156$ billion (Ways and Means Committee, $92^{\mathrm{d}}$ Congress, $1^{\text {st }}$ Session, “Actuarial Cost Estimates for The Old-Age, Survivors, and Disability Insurance System as Modified by the Social Security Provisions of Public Law 92-5," March 24, 1971, p. 7). Since this was for only 11 months of higher checks, this is an increase of $\$ 3.443$ billion at an annual rate. The retroactive payment, which was obviously temporary, was equal to four monthly payments, or $\$ 1.148$ billion. At an annual rate, this is $\$ 13.776$ billion.

Public Law 92-5 also included a spending-driven tax increase in January 1972 of \$3.1 billion (Romer and Romer, 2009, p. 54).

Public Law 92-336: Public Debt; Social Security Benefit Increase (enacted July 1, 1972) October 1972: $\$ 8$ billion permanent benefit increase

A 20 percent increase in Social Security benefits was attached to a bill increasing the ceiling on the national debt. The bill also put in place automatic indexing of benefits going forward.

The motivation for the increase is a bit opaque. In March 1971, an advisory council recommended a number of changes to Social Security, including a 5 percent increase in benefits. The recommendations became part of a bill (H. R. 1) that was debated in 1971 and 1972. President Nixon, in message to Congress, recommended passage of this legislation (Nixon, "Special Message to the Congress on Older Americans," March 23, 1972, p. 2). The motivation appeared to be to make benefits more adequate and more secure in the face of inflation. The Ways and Means Committee Report on the bill discussed the need to "guarantee that future inflationary changes in the prices of goods and services will not erode the purchasing power of their benefits" (Ways and Means Committee, $92^{\mathrm{d}}$ Congress, $1^{\text {st }}$ Session, House Report No. 92-231, "Social Security Amendments of 1971,” May 26, 1971, p. 5). The benefit increase grew to 20 percent and was included as a Senate amendment to the debt ceiling bill (Ball, "Social Security Amendments of 1972: Summary and Legislative History," Social Security Bulletin, March 1973, p. 12). President Nixon signed the legislation, but decried the fact that it was not completely self-financing. That he was concerned that the legislation threatened "to escalate the rate of inflation" suggests strongly that there was no countercyclical motivation to the bill (Nixon, "Statement on Signing a Bill Extending Temporary Ceiling on National Debt and Increasing Social Security Benefits,” July 1, 1972, p. 1).

The Social Security Bulletin said that the benefit increase was effective for September 1972, indicating the first higher checks would be received in October ("Social Security in Review: Social 
Security Provisions Amended," September 1972, p. 1). The 1973 Economic Report of the President gave an estimated annual cost of $\$ 8$ billion (p. 42). This number is broadly consistent with totals given in the 1973 Annual Report of the Board of Trustees of the Federal Old-Age and Survivors Insurance and Disability Insurance Trust Funds, which shows total disbursements in Fiscal Year 1972 of roughly $\$ 35$ billion (93 ${ }^{\mathrm{d}}$ Congress, $1^{\text {st }}$ Session, House Document No. 93-130, July 16, 1973, p. 6). A 20 percent increase would thus be $\$ 7$ billion. The increase was permanent.

Public Law 92-336 included increases in the earnings base for Social Security taxes in January 1973 and January 1974, and increases in the Social Security tax rate in 1973 and later years. However, all of these changes other than the 1973 increase in the base were amended by the Social Security Amendments of 1972 before they went into effect (Ball, "Social Security Amendments of 1972: Summary and Legislative History,” Social Security Bulletin, March 1973, p. 15). Together, the two laws increased taxes by $\$ 10.0$ billion in January 1973 and another $\$ 2.9$ billion in January 1978 (Romer and Romer, 2009, pp. 56-57). The 1973 change was spending-driven; the 1978 change, which was long after the spending increase, was for deficit reduction.

\section{Social Security Amendments of 1972 (enacted October 30, 1972) \\ February 1973: $\$ 2.3$ billion permanent benefit increase February 1974: \$1.4 billion permanent benefit increase}

The Social Security Amendments of 1972 included a number of further increases and reforms originally debated in H. R. 1 in 1971 and 1972, but not included in the July 1972 increase. It raised benefits for widows and widowers, increased minimum benefits, and liberalized disability provisions. It also included introduction of a new federal program to provide minimum benefits to needy aged, blind, and disabled people: Supplemental Security Income (SSI). SSI replaced an existing federalstate joint program. The law also included many Medicare provisions, including coverage of the disabled, which are not the focus of our study.

The motivation for the bill was not keeping up with inflation, since that had been taken care of in Public Law 92-336 in March 1972. According to the Senate Finance Committee report, "In addition to making more adequate provision for widows and for disabled persons, the committee bill contains several provisions aimed at strengthening the work incentive features of the social security system" (Senate Finance Committee, $92^{\mathrm{d}}$ Congress, $2^{\mathrm{d}}$ Session, Senate Report No. 92-1230, "Social Security Amendments of 1972," September 26, 1972, p. 135). President Nixon, in his signing statement, said the legislation "will end many old inequities and will provide a new uniform system of well-earned benefits for older Americans, the blind, and the disabled" (Nixon, "Statement on Signing the Social Security Amendments of 1972,” October 30, 1972, p. 1). The legislation was thus part of the reform process begun in 1971.

A committee print showed that most of the Social Security benefit increases were effective in January 1973, so the first higher checks would have come in February (Senate Finance Committee and Ways and Means Committee, 92 ${ }^{\mathrm{d}}$ Congress, $2^{\mathrm{d}}$ Session, "Summary of Social Security Amendments of 1972," November 17, 1972, pp. 1-8). The print gave an estimate of the increase in expenditures for Social Security cash benefits in calendar year 1974 (the first full year under the program) of $\$ 2.3$ billion (p. 40). The new payments for Supplemental Security Income were effective January 1974 ("Social Security in Review: Social Security Amendments of 1972," Social Security Bulletin, January 1973, p. 2). SSI payments were made at the end of the month, so we date the first checks as February 1974. The committee print set the increase in SSI benefit payments in 
1974 (which include 12 months of payments, so was at an annual rate) at $\$ 1.4$ billion (p. 43). Both benefit increases were permanent.

As discussed regarding Public Law 92-336, the Social Security Amendments of 1972 changed some of the financing provisions of the previous act before they took effect, with the end result that the two acts together raised taxes $\$ 10.0$ billion in January 1973 and $\$ 2.9$ billion in January 1978 (Romer and Romer, 2009, pp. 56-57).

Public Law 93-66: Extension of Renegotiation Act of 1951 (enacted July 11, 1973) Public Law 93-233 Social Security Benefit Increase (enacted December 31, 1973)

February 1974: $\$ 0.27$ billion permanent benefit increase April 1974: $\quad \$ \mathbf{\$ 4 . 0 7}$ billion permanent benefit increase July 1974: $\quad \$ 2.33$ billion permanent benefit increase August 1974: $\quad \$ 0.16$ billion permanent benefit increase

Public Law 93-66 included a Social Security benefit increase of 5.9 percent ("Social Security in Review: Social Security Act Amended,” Social Security Bulletin, September 1973, p. 1). It also raised SSI payments.

The motivation for the act was to provide a cost-of-living increase before automatic indexing took effect. Under the March 1972 act, which established indexing, the first automatic adjustment was to take place in January 1975. According to a committee print summarizing the act, "The new law provides for a special cost-of-living increase applicable only to benefits for June 1974 to December 1974, to be reflected in the checks people receive in early July 1974" (Senate Finance Committee and Ways and Means Committee, $93^{\mathrm{d}}$ Congress, $1^{\text {st }}$ Session, "Summary of the Provisions of the Acts Extending the Temporary Debt Ceiling and the Renegotiation Act, Including the Social Security Provisions,” July 17, 1973, p. 3). President Nixon reiterated this motivation in his signing statement, saying: "The critical feature of this bill ... is an increase in social security benefits of more than 5 percent next year in order to meet the rising costs of living" (Nixon, "Statement About Signing a Bill Increasing Social Security Benefits,” July 11, 1973, p. 1).

Before the benefit increases took effect, however, a larger benefit increase was passed in Public Law 93-233. This law raised cash benefits 11 percent in two steps: "7 percent payable with the benefit for March 1974 and 4 percent additional with the benefit for June" ("Social Security in Review: Social Security Act Amended," Social Security Bulletin, March 1974, p. 1). Automatic adjustment for inflation was then rescheduled to begin in July 1975. The new bill also increased SSI benefits further and made additional reforms to the program.

The motivation for the larger benefit increases was additional inflation. According to the Senate Finance Committee report: "Since this action [the July 1973 increase] was taken by the Congress, the cost of living has continued to rise, with a corresponding decline in the real income of about 30 million social security beneficiaries. The Committee believes that these beneficiaries should not have to wait until the middle of next year for a cost-of-living increase" (Senate Finance Committee, $93^{\mathrm{d}}$ Congress, $1^{\text {st }}$ Session, Senate Report No. 93-553, "Social Security Amendments of 1973,” November 21, 1973, p. 10). President Nixon gave a similar rationale for the action, saying: "The bill I sign today will replace that increase in order to reflect more closely the rise in the cost of living since the last social security increase took effect in September of 1972" (Nixon, Statement About Signing a Bill to Increase Social Security Benefits,” January 3, 1974, p. 1). 
The first stage of the increase affected benefits for March 1974 and so was reflected in April checks. To deduce the size of the increase, we use the summary of provisions for the earlier law, which said that a 5.6 percent increase for 7 months cost $\$ 1.9$ billion (Senate Finance Committee and Ways and Means Committee, $93^{\mathrm{d}}$ Congress, $1^{\text {st }}$ Session, "Summary of the Provisions of the Acts Extending the Temporary Debt Ceiling and the Renegotiation Act, Including the Social Security Provisions," July 17, 1973, p. 3). That implies that a 1 percent rise for 12 months cost \$0.5816 billion. Therefore, the 7 percent increase in April 1974 cost $\$ 4.07$ billion at an annual rate. In July there was a 4 percent increase, which by the same reasoning involved additional expenditures of $\$ 2.33$ billion at an annual rate. We deduce very similar estimates using figures in the report of the Senate Finance Committee (Senate Finance Committee, $93^{\mathrm{d}}$ Congress, $1^{\text {st }}$ Session, Senate Report No. 93-553, “Social Security Amendments of 1973," November 21, 1973, p. 77). The benefit increases were permanent.

The SSI benefit increases took place on a slightly different schedule: the first was effective in January 1974 (with the start of the federal Supplemental Security Income program); the second was effective in July ("Social Security in Review: Social Security Act Amended," Social Security Bulletin, March 1974, p. 1). Because SSI checks go out late in the month, we date the increases in February and August 1974. The SSI increases were not given as straight percentages but as dollar figures. The benefit increases work out to 7.7 percent for January and 4.3 percent for July. A committee print gave a gross cost of the SSI cash benefits in 1974 (under the Social Security Amendments of 1972) of \$3.5 billion (Senate Finance Committee and Ways and Means Committee, $92^{\mathrm{d}}$ Congress, $2^{\mathrm{d}}$ Session, "Summary of Social Security Amendments of 1972," November 17, 1972, p. 43). To calculate the cost of the benefit increase in January, we multiply $\$ 3.5$ billion times 7.7 percent, for an annual rate cost of $\$ 0.27$ billion. For the July increase we then multiply the resulting total of $\$ 3.77$ billion ( $\$ 3.5$ billion $+\$ 0.27$ billion) by 4.3 percent, for an annual rate cost of $\$ 0.16$ billion. These increases were also permanent. ${ }^{9}$

Both the pieces of Social Security legislation affected taxes. Together, they raised revenues by $\$ 4.2$ billion in January 1974. The motivation for the tax increase was to pay for the benefit increase (Romer and Romer, 2009, p. 58).

\section{Tax Reduction Act of 1975 (enacted March 29, 1975)}

The Tax Reduction Act of 1975 included a one-time payment of \$50 to all recipients of Social Security and SSI. This payment came from general revenues, not from the Social Security trust fund.

The motivation for this benefit payment was, like the rest of the act, to fight the recession occurring at the time. The Ways and Means Committee report on the bill, for example, said: "The U.S. economy has experienced its sharpest decline since the 1930's. The unemployment rate in

\footnotetext{
${ }^{9}$ When we want to use figures for benefit increases dated when they were enacted (rather than when they went into effect), we need to apportion the increases in Public Law 93-66 and Public Law 93-233 between the two acts. As noted above, Congress estimated that a Social Security benefit increase of 5.6 percent would cost $\$ 1.9$ billion over 7 months. Thus, since Public Law 93-66 increased Social Security benefits by 5.9 percent, we estimate the cost of its Social Security benefit increase at an annual rate as $\$ 1.9$ billion times 5.9/5.6 times 12/7, or $\$ 3.4316$ billion. We then assign the remainder of the total Social Security benefit increases of $\$ 6.4$ billion, or $\$ 2.9684$ billion, to the second act. For SSI, the February 1974 increase was legislated by Public Law 93-66 and the August 1974 increase was legislated by Public Law 93-233. We therefore assign $\$ 0.27$ billion to the first act and $\$ 0.16$ billion to the second. Thus, a total benefit increase of $\$ 3.7016$ billion was enacted on July 11, 1973, and a total increase of \$3.1284 billion was enacted on December 31, 1973.
} 
January 1975 was 8.2 percent, the highest since 1941, and actual output is over $\$ 200$ billion below potential output. This bill deals with these problems by providing a $\$ 20$ billion tax reduction in 1975” (Ways and Means Committee, 94 ${ }^{\text {th }}$ Congress, $1^{\text {st }}$ Session, House Report No. 94-19, “Tax Reduction Act of 1975,” February 25, 1975, p. 3). Likewise, in his signing statement, President Ford said: "Our country needs the stimulus and the support of a tax cut and needs it now. I have therefore decided to sign this bill so that its economic benefits can begin to work" (Ford, "Address to the Nation Upon Signing the Tax Reduction Act of 1975," March 29, 1975, pp. 1-2). Because the payment was clearly for countercyclical purposes, we exclude it from our analysis.

The payments to Social Security and SSI beneficiaries were made in May and June of 1975. According to a committee print, the cost of the one-time payment was $\$ 1.7$ billion (Ways and Means Committee, $94^{\text {th }}$ Congress, $1^{\text {st }}$ Session, "Summary of the Major Provisions of Public Law 94-12: Tax Reduction Act of 1975,” April 1, 1975, p. 16). Assuming all of those payments reached households in a single month, that would be $\$ 20.4$ billion at an annual rate. The payment was explicitly temporary.

\section{Cost-of-Living Adjustment (June 1975)}

July 1975: \$5.048 billion permanent benefit increase

Beginning in July 1975, Social Security benefits were automatically adjusted for inflation, provided the rise in the CPI over the previous year was more than 3 percent. The cost-of-living adjustments were effective in June, and so were first reflected in checks in July. The cost-of-living adjustment effective June 1975 was 8.0 percent (Social Security Administration, http://www.ssa.gov/oact/cola/colaseries.html). To deduce a dollar value for the increase in benefits, we multiply the National Income and Product Accounts (NIPA) figure for Social Security transfers in June 1975 by $0.08 .^{10}$ This gives an estimate of $\$ 5.048$ billion. All automatic cost-of-living adjustments were permanent. ${ }^{11}$

\section{Cost-of-Living Adjustment (June 1976)}

\section{July 1976: $\$ 4.608$ billion permanent benefit increase}

The cost-of-living increase effective June 1976 was 6.4 percent. Multiplying this percentage times the June number for Social Security transfers yields $\$ 4.608$ billion. The benefit increase appeared in checks in July.

\footnotetext{
${ }^{10}$ The monthly NIPA Social Security data are from the BEA, NIPA, Table 2.6, series for government social benefits to persons-Social Security, downloaded 1/23/2014. Our estimates of increases in benefits for the years before 1975 include increases in SSI payments as well as Social Security. While Social Security payments as defined in the NIPA data include payments from the Disability Insurance Trust Fund, they do not include SSI payments (which are grouped with miscellaneous government transfers in the "Other" category). For this reason, our estimates of the benefit increases from automatic cost-of-living adjustments are not precisely comparable to our estimates for the period before 1975. However, SSI payments are quite small, so this difference is unlikely to be consequential.

${ }^{11}$ The 1975 adjustment was to inflation over the period 1974:Q2-1975:Q1. The 1976-1984 adjustments were to inflation over the four quarters ending in the January-March quarter preceding the adjustment. Since 1985, the adjustments have been to inflation in the four quarters ending in the July-September quarter preceding the adjustment.
} 


\section{Cost-of-Living Adjustment (June 1977)}

\section{July 1977: $\$ 4.7495$ billion permanent benefit increase}

The cost-of-living increase effective June 1977 was 5.9 percent. We estimate the increase in benefits in July to have been $\$ 4.750$ billion.

\section{Social Security Amendments of 1977 (enacted December 20, 1977)}

The Social Security Amendments of 1977 were a comprehensive reform to restore long-run solvency to the Social Security system. The Senate Finance Committee report emphasized that the bill "includes several provisions designed to improve the financial status of the social security cashbenefits trust funds which, under present law, face serious deficit situations both over the long run and in the next several years" (Senate Finance Committee, $95^{\text {th }}$ Congress, $1^{\text {st }}$ Session, Senate Report No. 95-572, “Social Security Amendments of 1977," November 1, 1977, p. 1). President Carter, in his signing statement, said that the legislation would assure "that the social security system will be financially sound well into the next century" (Carter, "Social Security Amendments of 1977 Statement on Signing S. 305 into Law,” December 20, 1977, p. 1).

The primary benefit change involved correcting a flaw in the benefit formula that essentially corrected for inflation twice. This change, though large, only affected future beneficiaries and had no immediate impact on benefits paid. According to a Senate Finance Committee print summarizing the amendments, overall OASDI benefits would be reduced $\$ 440$ million in calendar year 1978 (Senate Finance Committee, $95^{\text {th }}$ Congress, $1^{\text {st }}$ Session, "Summary of H. R. 9346, the Social Security Amendments of 1977 as Passed by the Congress," December 23, 1977, p. 16). The source of this change was various small provisions, such as the elimination of retroactive benefits for people for whom the payment would lead to permanently reduced benefits. Since most of these provisions also applied only to new beneficiaries, we do not include them in our analysis.

The Social Security Amendments of 1977 included a number of tax increases, all of which were designed to deal with the long-run solvency problems of the Social Security system. There were increases of $\$ 8.8$ billion in January 1979; $\$ 1.7$ billion in January 1980; $\$ 17.2$ billion in January 1981; and $\$ 1.5$ billion in January 1982. Later tax increases called for in the legislation were modified by the Social Security Amendments of 1983 (Romer and Romer, 2009, pp. 62-64).

\section{Cost-of-Living Adjustment (June 1978)}

July 1978: $\$ 5.72$ billion permanent benefit increase

The cost-of-living increase effective June 1978 was 6.5 percent. We estimate the increase in benefits in July to have been $\$ 5.72$ billion.

\section{Cost-of-Living Adjustment (June 1979)}

\section{July 1979: \$9.6525 billion permanent benefit increase}

The cost-of-living increase effective June 1979 was 9.9 percent. We estimate the increase in benefits in July to have been $\$ 9.653$ billion. 


\section{Cost-of-Living Adjustment (June 1980)}

\section{July 1980: $\$ 15.7872$ billion permanent benefit increase}

The cost-of-living increase effective June 1980 was 14.3 percent. We estimate the increase in benefits in July to have been $\$ 15.787$ billion.

\section{Cost-of-Living Adjustment (June 1981)}

July 1981: \$14.7504 billion permanent benefit increase

The cost-of-living increase effective June 1981 was 11.2 percent. We estimate the increase in benefits in July to have been $\$ 14.750$ billion.

\section{Cost-of-Living Adjustment (June 1982)}

\section{July 1982: $\$ 10.8854$ billion permanent benefit increase}

The cost-of-living increase effective June 1982 was 7.4 percent. We estimate the increase in benefits in July to have been $\$ 10.885$ billion.

\section{Social Security Amendments of 1983 (enacted April 20, 1983)}

\section{August 1983: \$0.75 billion permanent benefit increase}

The Social Security Amendments of 1983 implemented the consensus recommendations of the National Committee on Social Security Reform. It was primarily designed to ensure the actuarial soundness of the Social Security system. The Ways and Means Committee report said: "The primary focus of your Committee's bill is on restoring the financial soundness of the old age and survivors' insurance (OASI) program, which is facing severe cash shortfalls over the next 7 years" (Ways and Means Committee, $98^{\text {th }}$ Congress, $1^{\text {st }}$ Session, House Report No. 98-25, Part 1, "Social Security Act Amendments of 1983,” March 4, 1983, p. 1). President Reagan in his signing remarks said: "We promised that we would protect the financial integrity of social security. We have" (Reagan, “Remarks on Signing the Social Security Amendments of 1983,” April 20, 1983, p. 1).

Most of the benefit changes were either small changes relative to current law or affected only new beneficiaries. For example, the automatic cost-of-living increase scheduled for July 1983 was postponed until January 1984, and cost-of-living adjustments from then on were scheduled to occur in January (Svahn and Ross, "Social Security Amendments of 1983: Legislative History and Summary Provisions," Social Security Bulletin, July 1983, p. 25). This was a change in benefits relative to current law, not an actual decline in July 1983, so is not included in our sample. Likewise, the act gradually raised the retirement age. This change explicitly exempted those near retirement. The act also extended the Federal Supplemental Compensation program, which provided extra weeks of unemployment compensation benefits. Because such extensions in unemployment insurance inherently have a countercyclical component, it too is excluded.

The one benefit change that is relevant for our study is a permanent increase in SSI benefits effective July 1, 1983. The Ways and Means Committee report explained that this increase "would be in lieu of the cost-of-living increase in the Federal SSI benefits standard that would occur July 1, 1983 under current law” (Ways and Means Committee, $98^{\text {th }}$ Congress, $1^{\text {st }}$ Session, House Report No. 
98-25, Part 1, “Social Security Act Amendments of 1983,” March 4, 1983, p. 109). The amendments delayed the automatic cost-of-living adjustment for SSI to January 1984. Because SSI checks come late in the month, we date the increase in benefits in August 1983. The Senate Finance Committee report gave the cost of the SSI increase (based on Congressional Budget Office estimates) as \$750 million in fiscal year 1984 (the first full year under the law) (Senate Finance Committee, 98 ${ }^{\text {th }}$ Congress, $1^{\text {st }}$ Session, Senate Report No. 98-23, “Social Security Act Amendments of 1983,” March 11, 1983, p. 69).

The Social Security Amendments of 1983 included a number of tax increases, all aimed at dealing with the long-run solvency of the program. The increases were $\$ 12.1$ billion in January 1984; \$8.8 billion in January 1985; \$4.2 billion in January 1986; \$15.5 billion in January 1988; and $\$ 10.3$ billion in January 1990 (Romer and Romer, 2009, pp. 72-73).

\section{Retroactive Payments (November and December 1983) \\ November 1983: $\$ 5.3$ billion one-time payment \\ December 1983: $\$ 6.4$ billion one-time payment}

According to an Associated Press (AP) news article: "A modernized data processing system has helped the Social Security Administration catch up with a backlog of cases which needed to be recomputed” (Miami News, “2 Million Social Security Checks to be a Little Fatter,” October 19, 1983, p. 3A). The article said retroactive payments averaged $\$ 1000$ for those receiving them, and gave a date for the arrival of the checks as "about December 3." As described in Section I, for cases such as this where we can identify a retroactive payment, we use the increase in the NIPA Social Security transfers measure in the relevant month. Because the timing is ambiguous and appears to be spread over November and December 1983, we include both months. There were increases of \$5.3 billion in November 1983 and \$1.1 billion in December 1983. Since the December increase was on top of the increase in November, our estimate of the one-time payment in December is the November increase ( $\$ 5.3$ billion) plus the December increase ( $\$ 1.1$ billion), for a total of $\$ 6.4$ billion. Because these are one-time retroactive payments, we classify them as temporary.

\section{Cost-of-Living Adjustment (December 1983)}

January 1984: \$5.9535 billion permanent benefit increase

The Social Security Amendments of 1983 delayed the July 1983 COLA for 6 months. The cost-of-living increase effective December 1983 was 3.5 percent. We estimate the increase in benefits in January 1984 to have been $\$ 5.954$ billion.

\section{Retroactive Payment (December 1984) \\ December 1984: $\$ 8.6$ billion one-time payment}

An AP news article said a group of beneficiaries (those who had earnings in 1982) had their checks recomputed and would be getting retroactive payments averaging $\$ 480$ per person (Spartanburg Herald-Journal, “Social Security Benefits Going Up,” October 31, 1984, p. A3). The checks were expected in December. The rise in Social Security transfers in December 1984 was \$8.6 billion, which we use as our estimate of the size of the payment. This figure is moderately smaller than that implied by the article, which said more than 2 million people would get benefits averaging 
$\$ 480$, implying an increase at an annual rate of about $\$ 12$ billion. The one-time payment was temporary.

\section{Cost-of-Living Adjustment (December 1984)}

January 1985: \$6.37 billion permanent benefit increase

The cost of living increase effective December 1984 was 3.5 percent. We estimate the increase in benefits in January 1985 to have been $\$ 6.37$ billion.

\section{Retroactive Payment (July 1985)}

July 1985: \$5.7 billion one-time payment

An AP news story on personal income in July 1985 reported a "\$5-billion growth in retroactive Social Security payments that resulted from a recalculation of benefits for people who are still working while drawing payments" (Lewiston (Maine) Daily Sun, "S. S. Benefits Hike Aids U.S. Income Rise,” August 20, 1985, p. 8). The rise in NIPA Social Security transfers for that month was $\$ 5.7$ billion, which is the estimate we use. The increase was temporary.

\section{Cost-of-Living Adjustment (December 1985)}

\section{January 1986: $\$ 5.7195$ billion permanent benefit increase}

The cost-of-living increase effective December 1985 was 3.1 percent. We estimate the increase in benefits in January 1986 to have been $\$ 5.720$ billion.

\section{Retroactive Payment (July 1986)}

\section{July 1986: \$6.3 billion one-time payment}

An AP news story on personal income for July 1986 stated: “The government said a large part of the increase came from retroactive adjustments to Social Security benefits for recent retirees" (Sarasota Herald-Tribune, "Personal Income Up; Housing Starts Fall,” August 21, 1986, p. 1D). The average payment for those receiving the adjustment was \$265 (Wall Street Journal, “Social Security Payments to Increase for 2 Million,” July 1, 1986, p. 2). The increase in NIPA Social Security transfers in July 1986 was $\$ 6.3$ billion, which is very similar to the annual rate implied by the Wall Street Journal's statement that the retroactive benefits “will be more than $\$ 500$ million” (p. 2). The increase was temporary.

\section{Cost-of-Living Adjustment (December 1986)}

\section{January 1987: $\$ 2.548$ billion permanent benefit increase}

The Omnibus Budget Reconciliation Act of 1986 (signed October 21, 1986), eliminated the 3 percent minimum for the cost-of-living adjustment. The cost-of-living increase effective December 1986 was 1.3 percent. We estimate the increase in benefits in January 1987 to have been \$2.548 billion. 
Retroactive Payment (May 1987)

May 1987: \$6.4 billion one-time payment

An AP article on personal income for June 1987 said: “The June and May increases in personal incomes were affected by a large increase in retroactive payments for Social Security benefits, which inflated the May advance” (New York Times, "June Spending Up 0.7\% As Incomes Gained 0.4\%," July 28, 1987, p. D2). The rise in NIPA Social Security transfers in May was $\$ 6.4$ billion. The increase was temporary.

Cost-of-Living Adjustment (December 1987)

January 1988: $\$ 8.4798$ billion permanent benefit increase

The cost-of-living increase effective December 1987 was 4.2 percent. We estimate the increase in benefits in January 1988 to have been $\$ 8.480$ billion.

\section{Retroactive Payment (March 1988)}

March 1988: \$4.9 billion one-time payment

An AP article on personal income for May 1988 reported: "March income was boosted by profit-sharing payments to auto workers and retroactive Social Security payments" (Reading Eagle, "May Personal Income Up Slightly," June 24, 1988, p. 27). The rise in NIPA Social Security transfers in March was $\$ 4.9$ billion. The increase was a temporary, one-time payment.

\section{Cost-of-Living Adjustment (December 1988)}

January 1989: $\$ 8.58$ billion permanent benefit increase

The cost-of-living increase effective December 1988 was 4.0 percent. We estimate the increase in benefits in January 1989 to have been $\$ 8.58$ billion.

\section{Retroactive Payment (March 1989)}

\section{March 1989: \$6.2 billion one-time payment}

An article in the New York Times reported that "the March slowdown [in personal income growth] came despite huge special payments to Americans that month. ... [T] [Te Social Security Administration paid retroactive increases in benefits" (New York Times, "The Savings Rate Keeps Climbing,” April 28, 1989, p. D1). The rise in NIPA Social Security transfers in March was $\$ 6.2$ billion. The increase was temporary.

\section{Retroactive Payment (November 1989) \\ November 1989: $\$ 3.7$ billion one-time payment}

An AP article on the December rise in personal incomes explained that the rise "was reduced by decreases in retroactive Social Security benefit payments and in subsidy payments to farm proprietors” (Daily Gazette, “Personal Income, Spending Reported Higher,” January 30, 1990, p. 
D12). This discussion implies that there had been a rise in retroactive payments in the previous month (November 1989). The increase in NIPA Social Security transfers in November was \$3.7 billion. The increase was temporary.

\section{Cost-of-Living Adjustment (December 1989)}

January 1990: \$10.7442 billion permanent benefit increase

The cost-of-living adjustment effective December 1989 was 4.7 percent. We estimate the increase in benefits in January 1990 to have been $\$ 10.744$ billion.

\section{Cost-of-Living Adjustment (December 1990)}

January 1991: \$13.4892 billion permanent benefit increase

The cost-of-living adjustment effective December 1990 was 5.4 percent. We estimate the increase in benefits in January 1991 to have been $\$ 13.489$ billion. 


\section{TRANSFER PAYMENTS AND THE MACROECONOMY: THE EFFECTS OF SOCIAL SECURITY BENEFIT INCREASES, 1952-1991 \\ Christina D. Romer \\ David H. Romer \\ ONLINE APPENDix B \\ SUPPLEMENTAL FIGURES}

This appendix presents the figures corresponding to the robustness checks described in the text. In particular, Figures B1 through B4 show the auxiliary figures for Section I of the paper; Figures B5 through B9 show those for Section II; and Figures B10 through B18 show those for Section III. 


\section{FIGURE B1}

Baseline Consumption Results for Alternative Sample Periods

(Cumulative Impact of a Benefit Increase of 1 Percent of Personal Income on Consumption)

a. 1959:2-1991:12

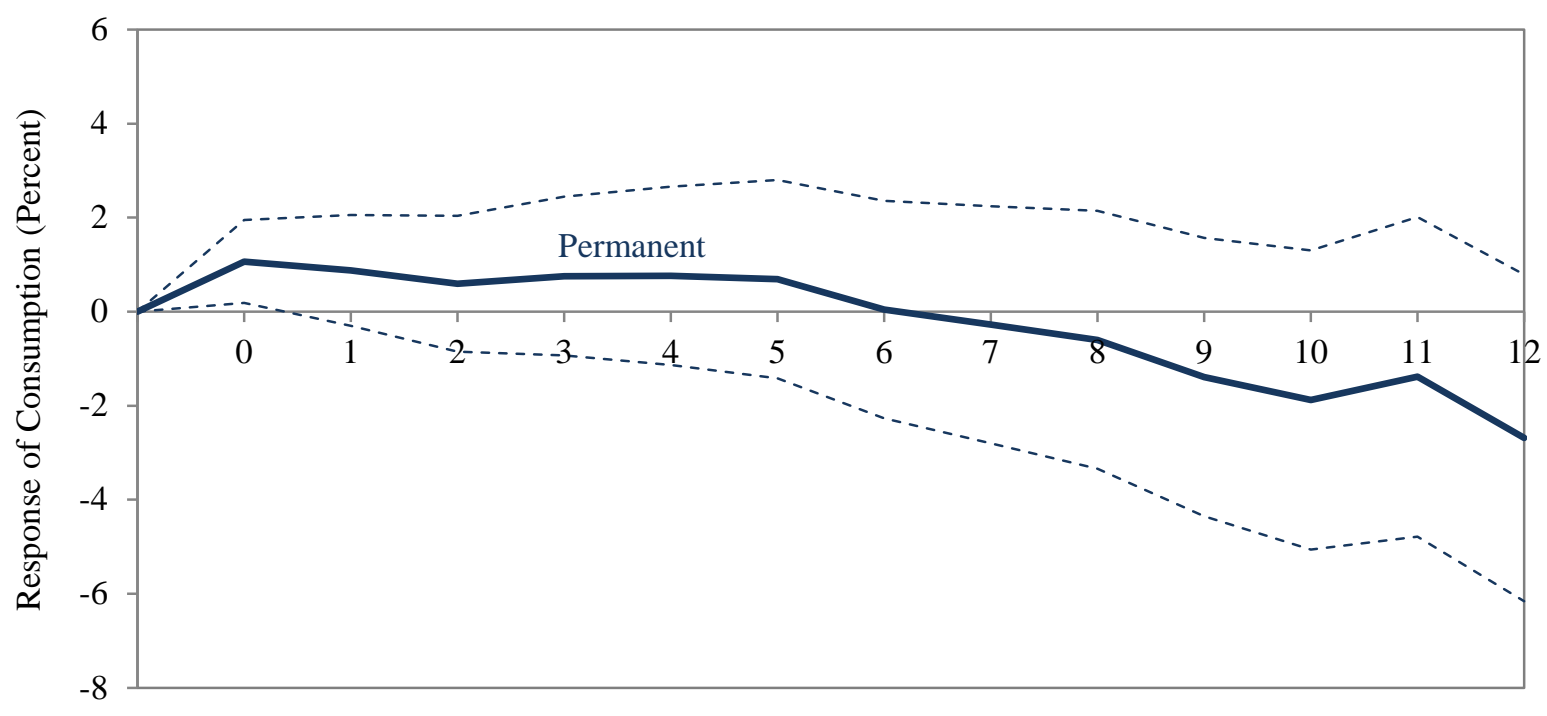

Months after the Increase

b. 1952:1-1974:12

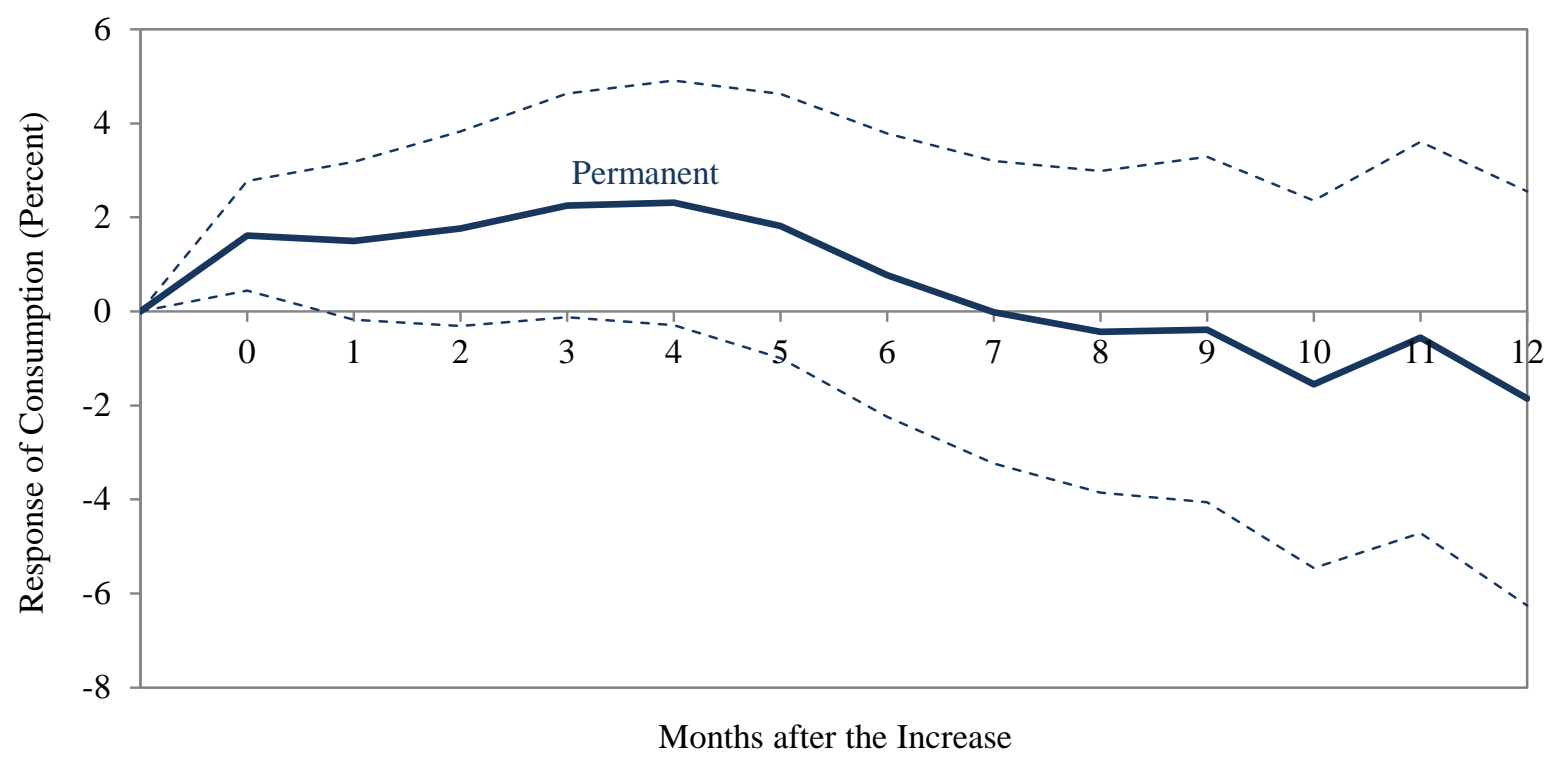




\section{FIGURE B1 (Continued)}

Baseline Consumption Results for Alternative Sample Periods

(Cumulative Impact of a Benefit Increase of 1 Percent of Personal Income on Consumption)

c. $1975: 1-1991: 12$

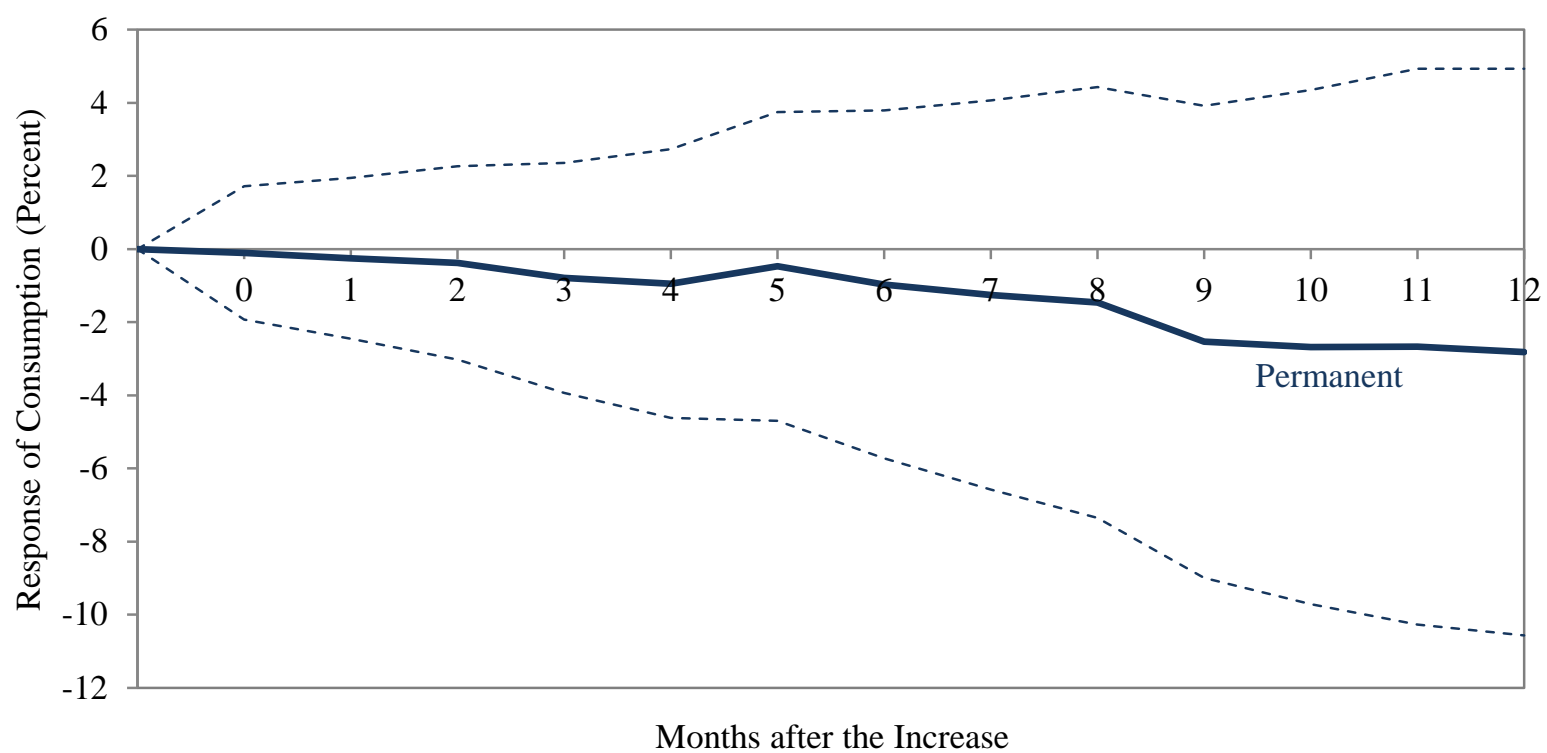

Notes: The figures show the results from estimating equation (2) over various alternative sample periods, including the contemporaneous value and 12 lags of both permanent and temporary benefit increases. The dashed lines show the two-standard-error confidence bands. 


\section{FIGURE B2}

Baseline Consumption Results Including Three Leads

(Regression Coefficients and Cumulative Impact of a Benefit Increase of 1 Percent of Personal Income)

\section{a. Regression Coefficients for Permanent Benefit Increases}

\begin{tabular}{cccc}
$\begin{array}{c}\text { Lag of the Permanent } \\
\text { Benefits Variable }\end{array}$ & $\begin{array}{c}\text { Coefficient } \\
\text { Estimate }\end{array}$ & Standard Error & t-Statistic \\
\hline-3 & -0.41 & 0.43 & -0.94 \\
-2 & 0.12 & 0.43 & 0.27 \\
-1 & -0.51 & 0.43 & -1.17 \\
0 & 1.24 & 0.43 & 2.84 \\
1 & -0.19 & 0.37 & -0.52 \\
2 & -0.13 & 0.37 & -0.34 \\
3 & 0.09 & 0.37 & 0.23 \\
4 & -0.05 & 0.37 & -0.14 \\
5 & -0.10 & 0.37 & -0.26 \\
6 & -0.62 & 0.37 & -1.68 \\
7 & -0.39 & 0.37 & -1.05 \\
8 & -0.37 & 0.37 & -1.00 \\
9 & -0.54 & 0.44 & -1.24 \\
10 & -0.63 & 0.44 & -1.43 \\
11 & 0.80 & 0.44 & 1.81 \\
12 & -1.43 & 0.44 & -3.26 \\
\hline
\end{tabular}

\section{b. Cumulative Impact on Consumption}

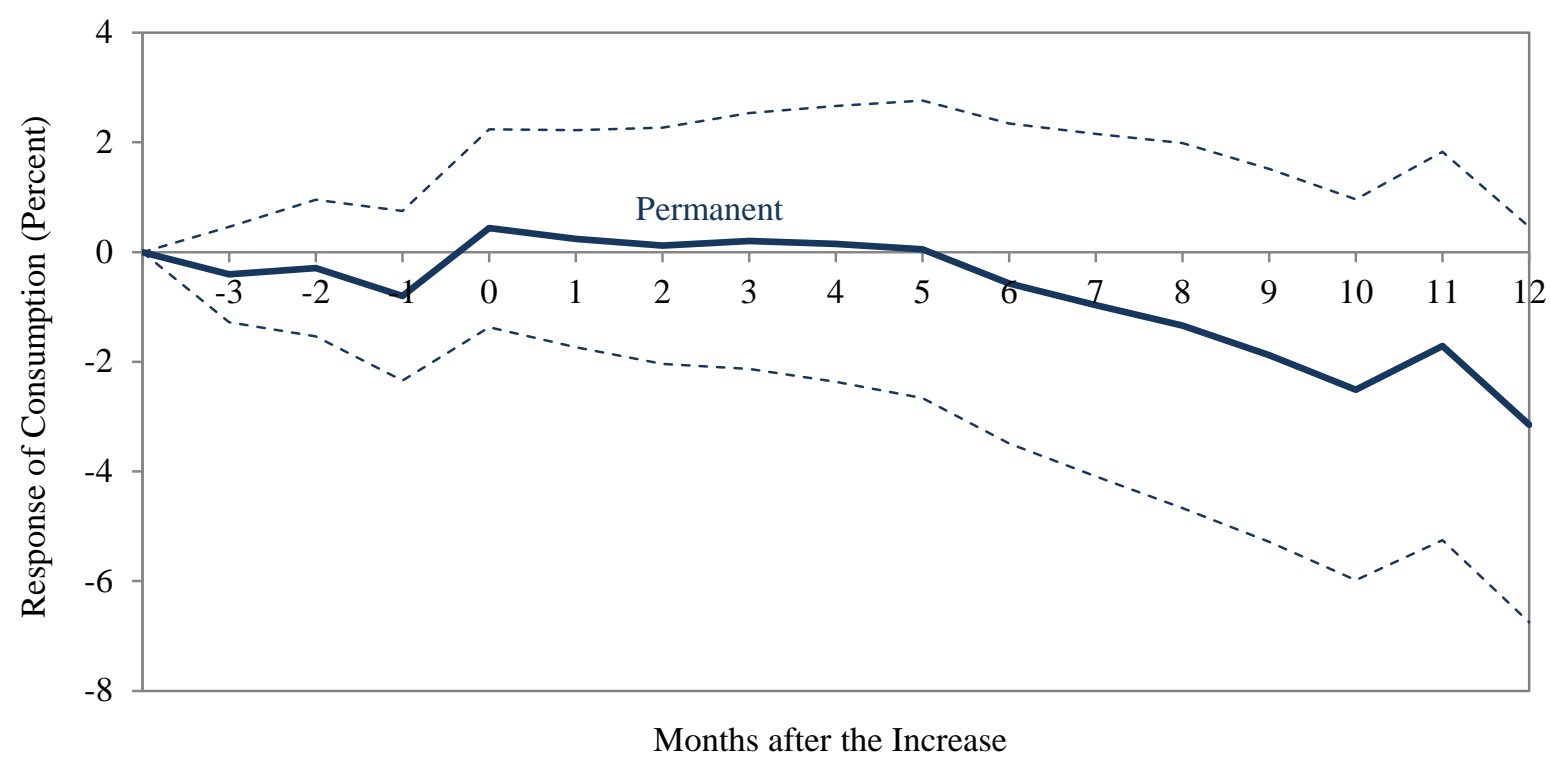

Notes: The regression coefficients and the figure show the results from estimating equation (2) over the sample period 1952:1-1991:12, including 3 leads, the contemporaneous value, and 12 lags of both permanent and temporary benefit increases. The dashed lines show the two-standard-error confidence bands. 


\section{FIGURE B3}

Consumption Results Including Various Control Variables

(Cumulative Impact of a Benefit Increase of 1 Percent of Personal Income on Consumption)

a. Controlling for the Contemporaneous Value and 12 Lags of Oil Price Inflation

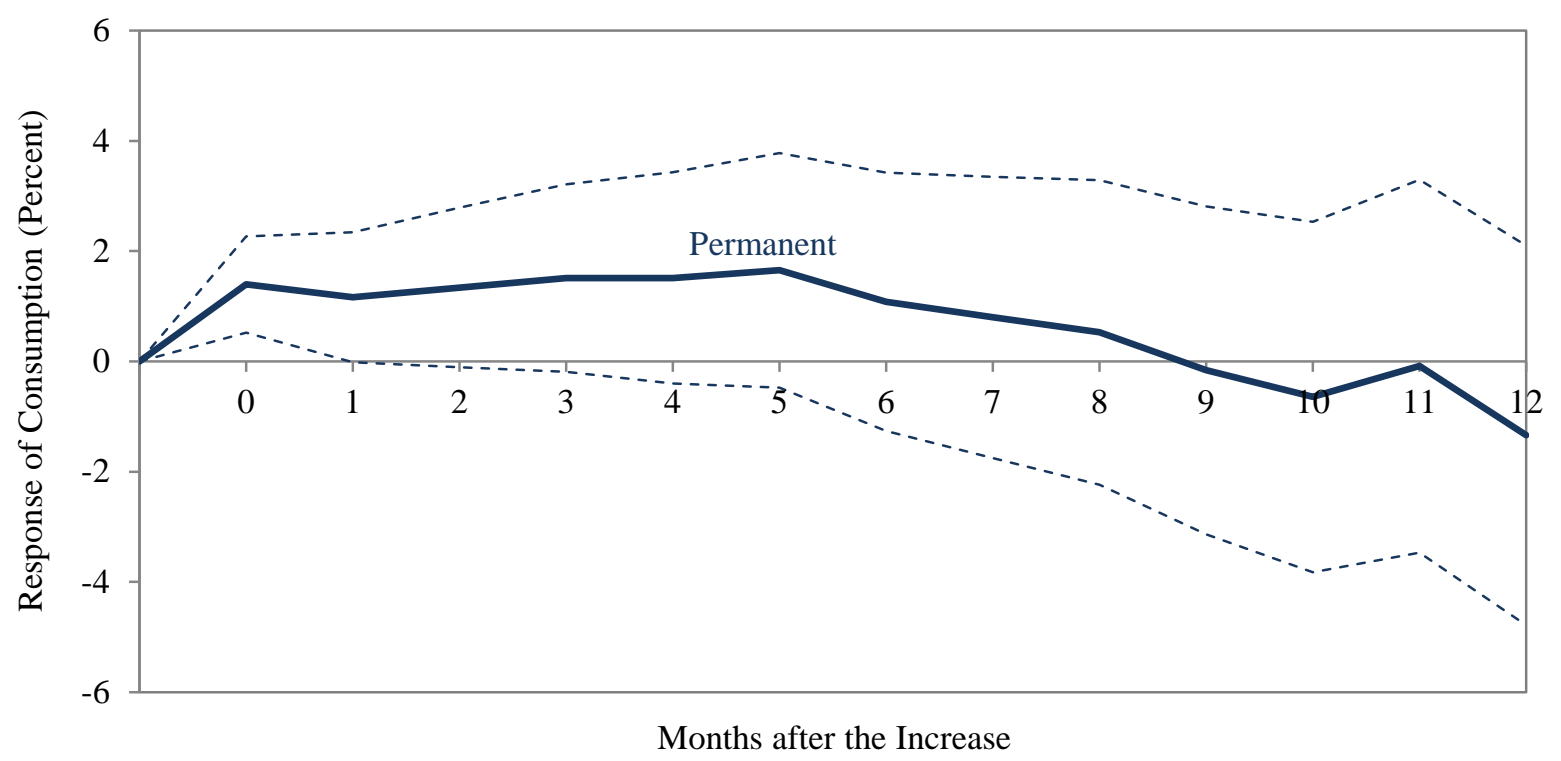

b. Controlling for the Contemporaneous Value and 12 Lags of Monetary Policy Shocks

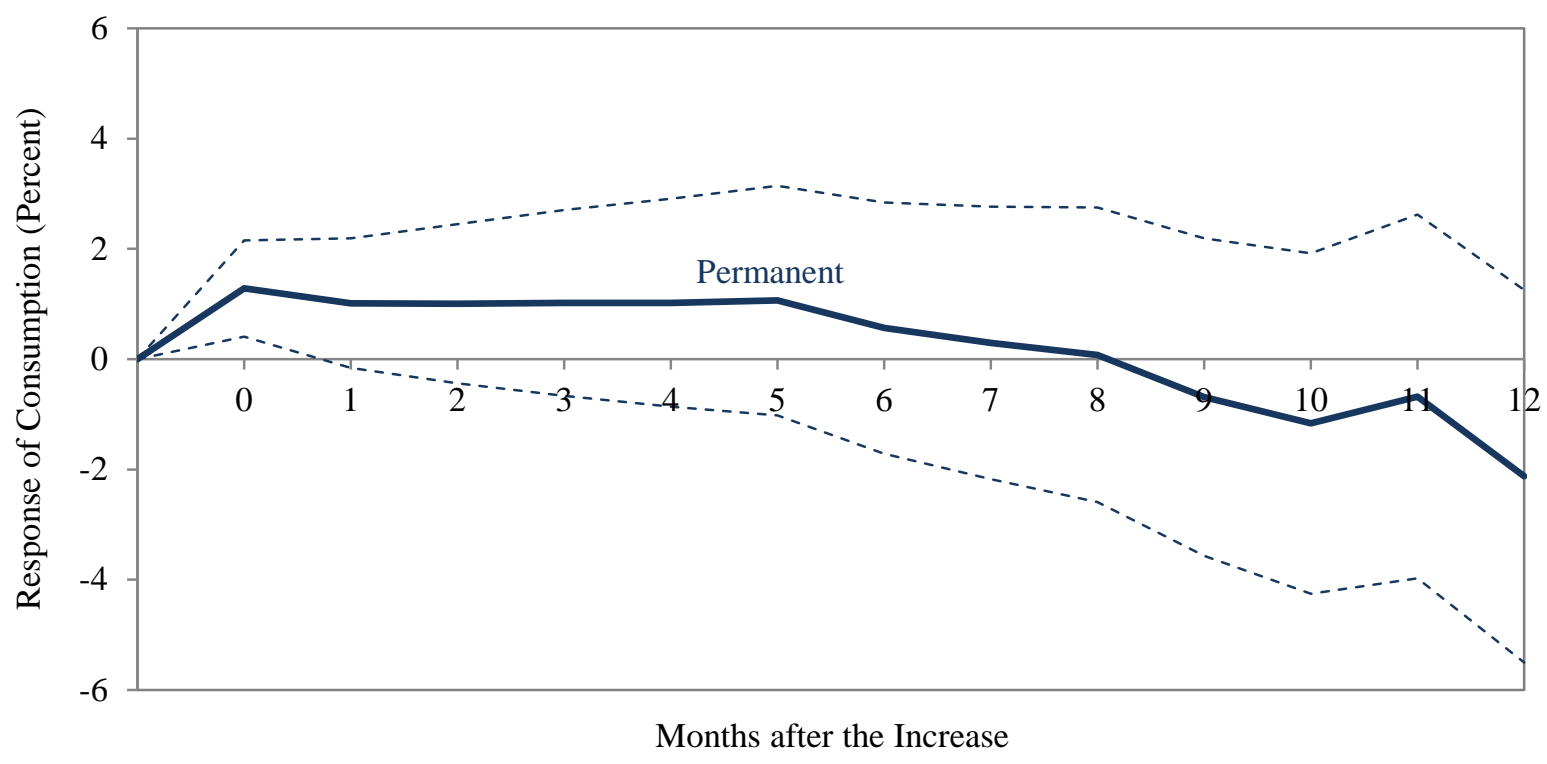




\section{FIGURE B3 (Continued) \\ Consumption Results Including Various Control Variables}

(Cumulative Impact of a Benefit Increase of 1 Percent of Personal Income on Consumption)

\section{c. Controlling for the Contemporaneous Value and 24 Lags of Monetary Policy Shocks}

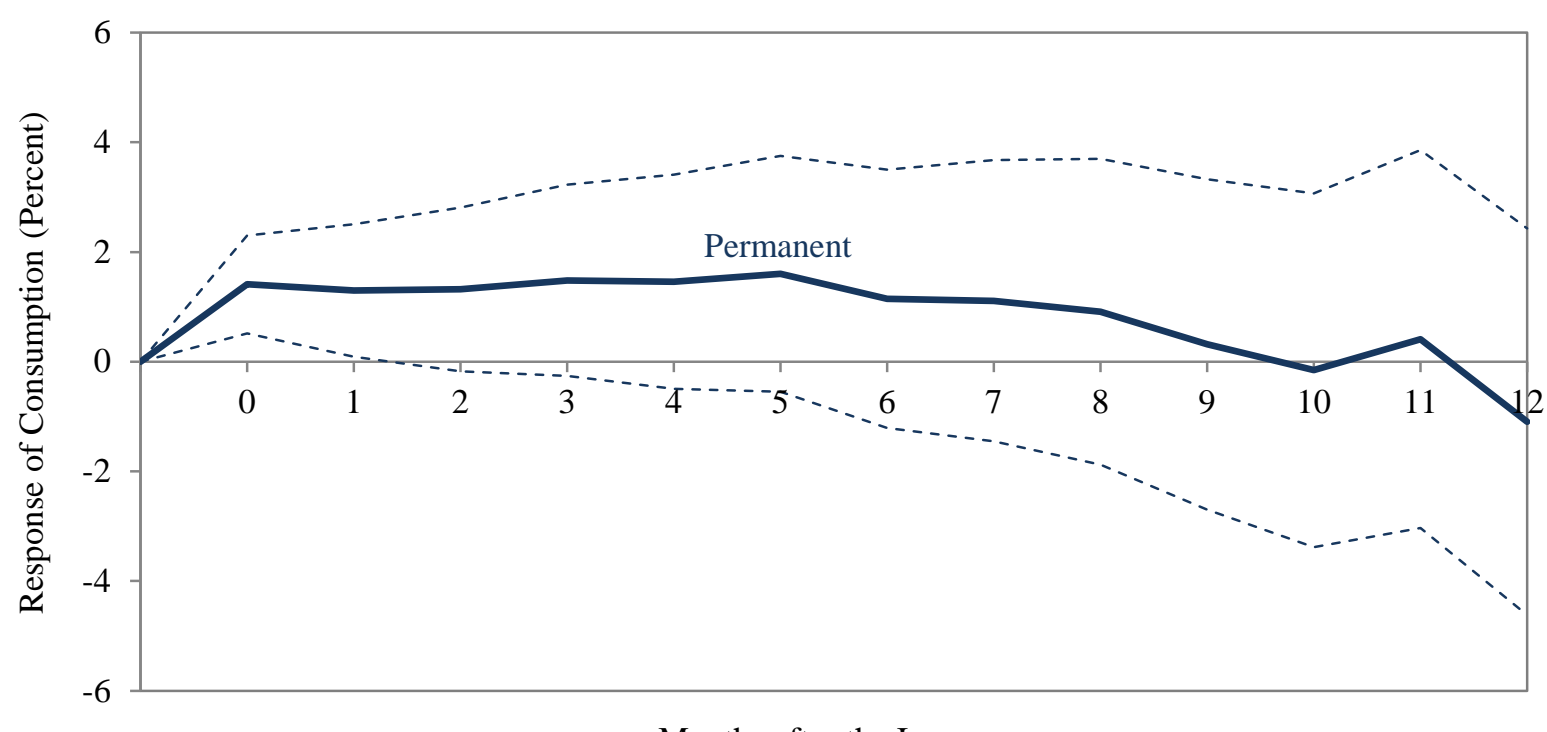

Months after the Increase

Notes: The figures show the results from estimating equation (2) over the sample period 1952:1-1991:12, including the contemporaneous value and 12 lags of both permanent and temporary benefit increases, and including various additional control variables. Panel (a) includes the contemporaneous value and 12 lags of the change in the logarithm of oil prices; panel (b) includes the contemporaneous value and 12 lags of the Romer and Romer dummy variable for shifts to contractionary monetary policy; and panel (c) includes the contemporaneous value and 24 lags of the Romer and Romer dummy. See the text for the details and the sources of the control variables. The dashed lines show the two-standard-error confidence bands. 


\section{FIGURE B4}

Consumption Results Estimated Using the Jordà Local Projection Approach

(Cumulative Impact of a Benefit Increase of 1 Percent of Personal Income on Consumption)

\section{a. Three Variables (Consumption, Permanent and Temporary Benefit Increases)}

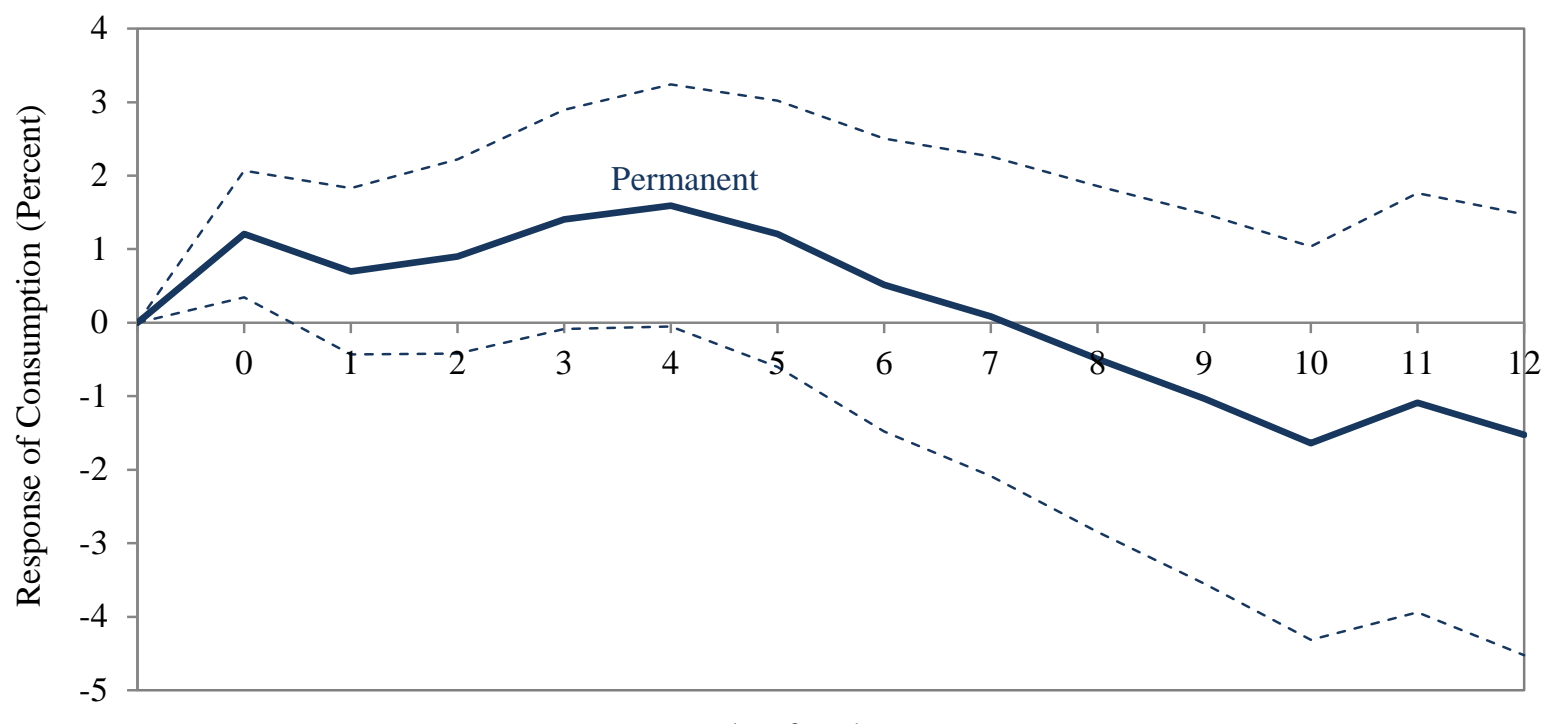

Months after the Increase

\section{b. Four Variables (Consumption, Permanent and Temporary Benefit Increases, Prices)}

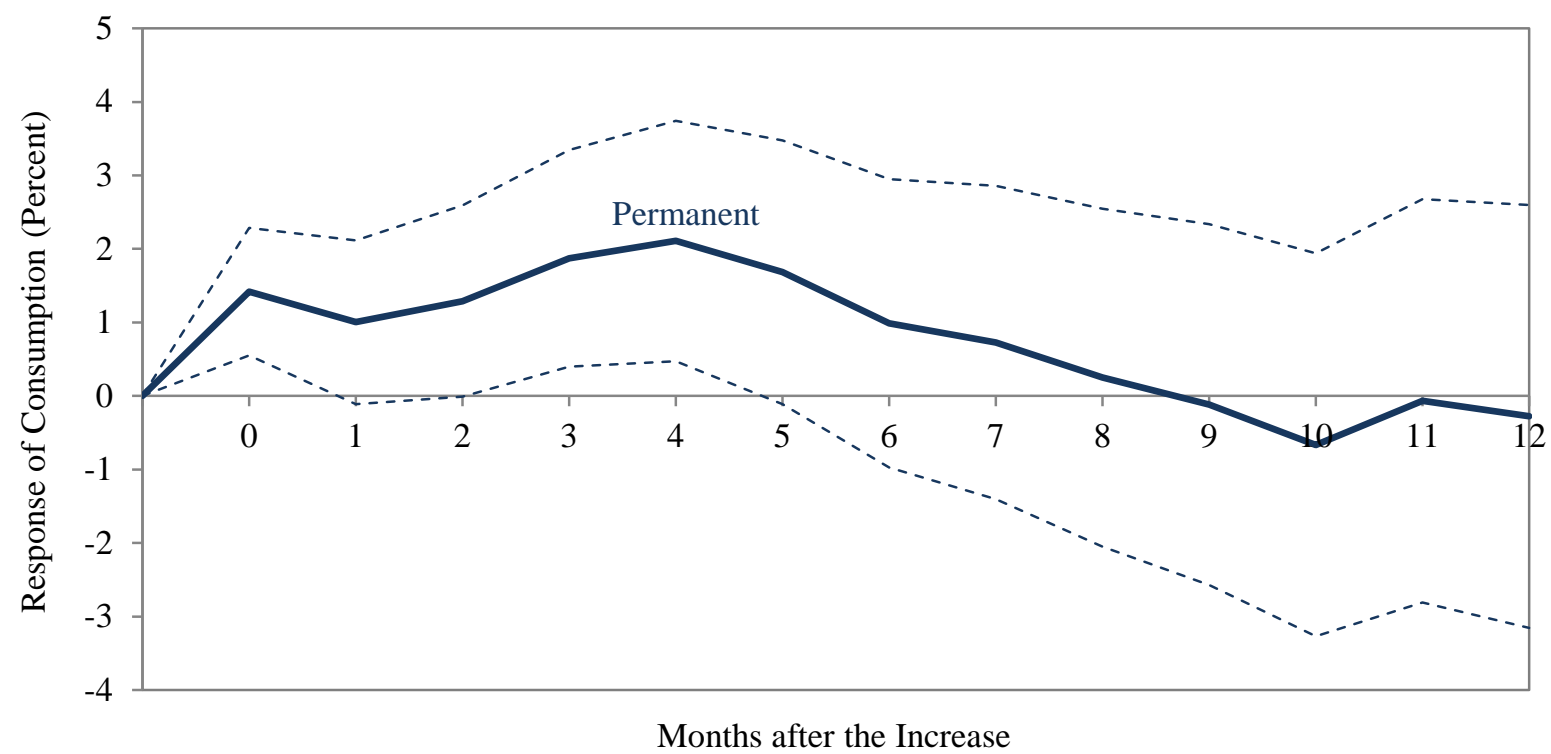

Notes: The responses in each figure are estimated by regressing the logarithm of consumption at various horizons after time $t$ on permanent and temporary benefit increases at time $t$. Panel (a) includes 12 lags of each of permanent benefit increases, temporary benefit increases, and the logarithm of consumption as controls. Panel (b) includes the same controls plus 12 lags of the logarithm of prices. The data used are for 1952:1-1991:12. The dashed lines show the two-standard-error confidence bands. 


\section{FIGURE B5}

\section{Consumption Results for Benefit Increases and Tax Cuts (Including Business Tax Changes)} (Cumulative Impact of a Benefit Increase and a Tax Cut of 1 Percent of Personal Income on Consumption)

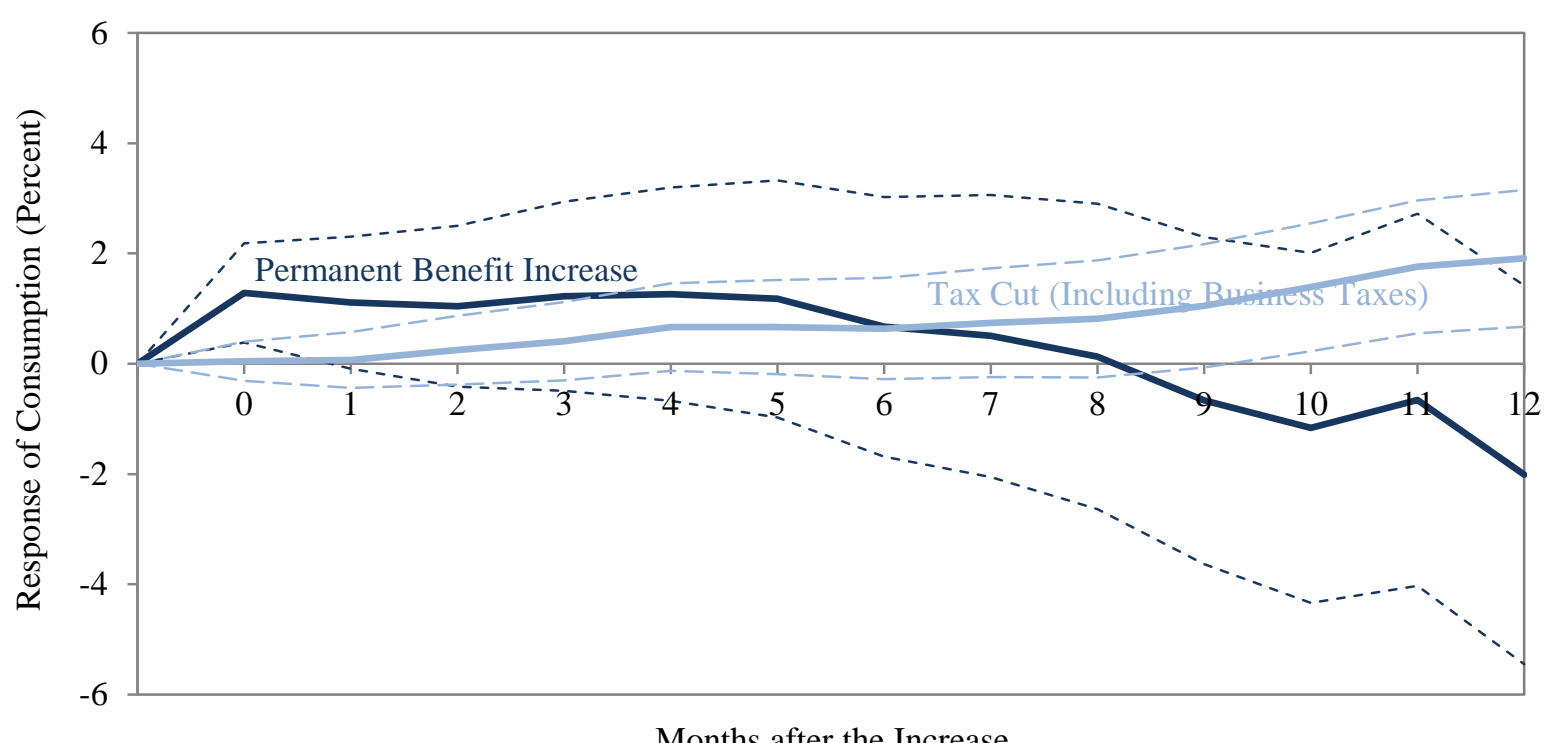

Notes: The figure shows the results from estimating equation (2) including the contemporaneous value and 12 lags of both permanent and temporary benefit increases, and including the contemporaneous value and 24 lags of the tax variable as additional controls. The tax variable used includes business tax changes; see text for details. The sample period is 1952:1-1991:12. The dashed lines show the two-standard-error confidence bands. 


\section{FIGURE B6 \\ Consumption Results for Benefit Increases with and without Tax Changes \\ (Cumulative Impact of a Benefit Increase of 1 Percent of Personal Income on Consumption)}

\section{a. Permanent Benefit Increase}

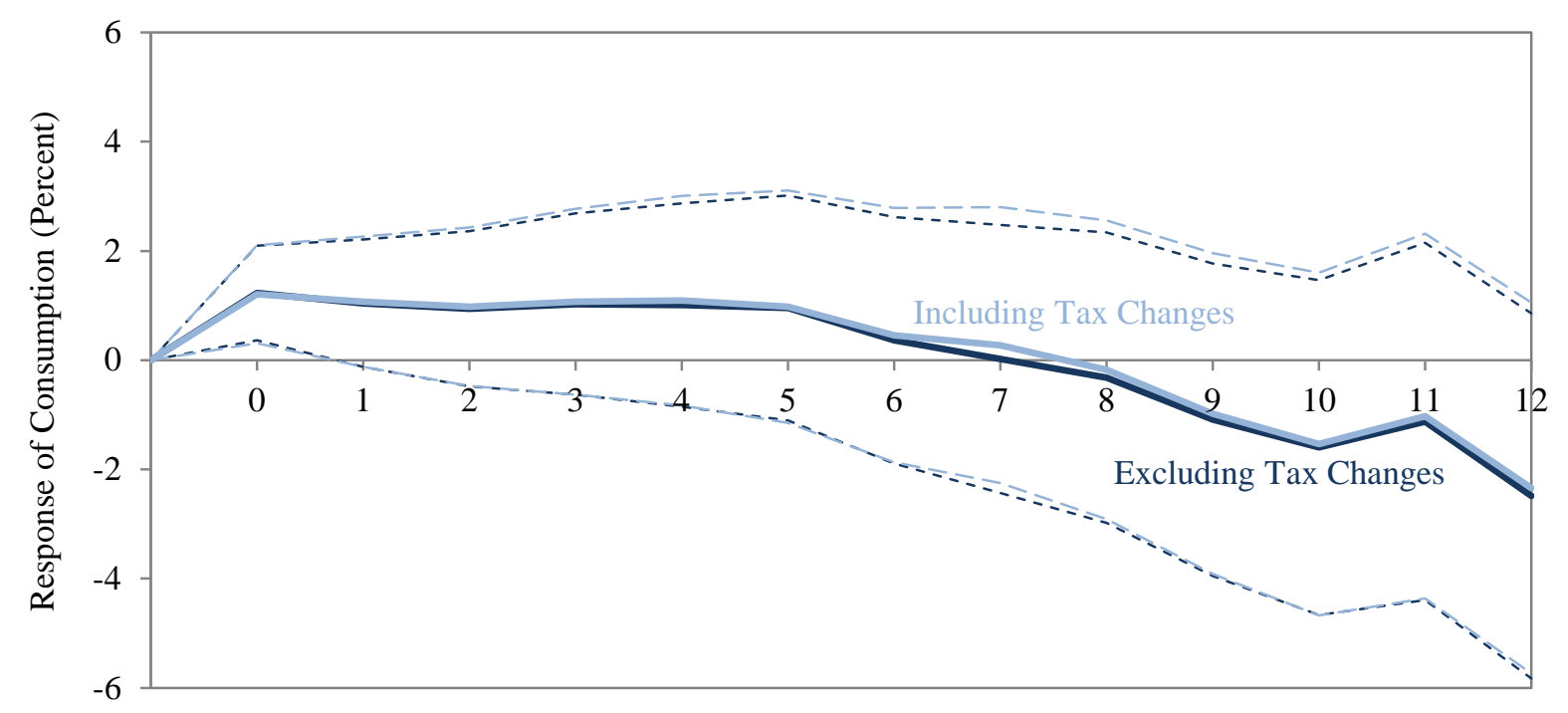

Months after the Increase

\section{b. Temporary Benefit Increase}

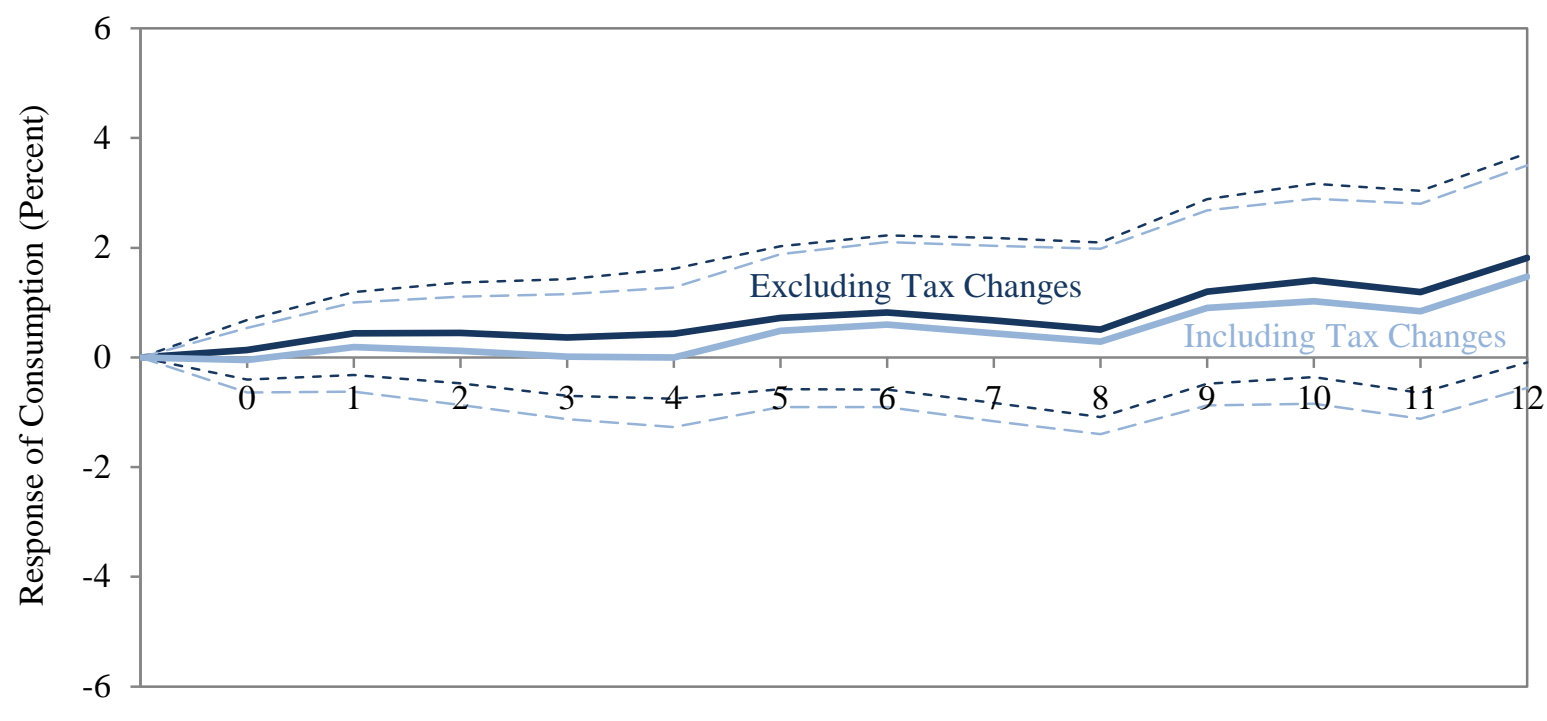

Months after the Increase

Notes: The dark blue line in each panel shows the baseline results from estimating equation (2) including the contemporaneous value and 12 lags of both permanent and temporary benefit increases. The light blue line in each panel shows the results from estimating equation (2) including the contemporaneous value and 12 lags of both permanent and temporary benefit increases, and including the contemporaneous value and 24 lags of the tax variable as additional controls. The sample period is 1952:1-1991:12. The dashed lines show the two-standard-error confidence bands. 


\section{FIGURE B7 \\ Consumption Results Going out 24 Months}

(Cumulative Impact of a Benefit Increase and a Tax Cut of 1 Percent of Personal Income on Consumption)

\section{a. Impact of a Tax Cut}

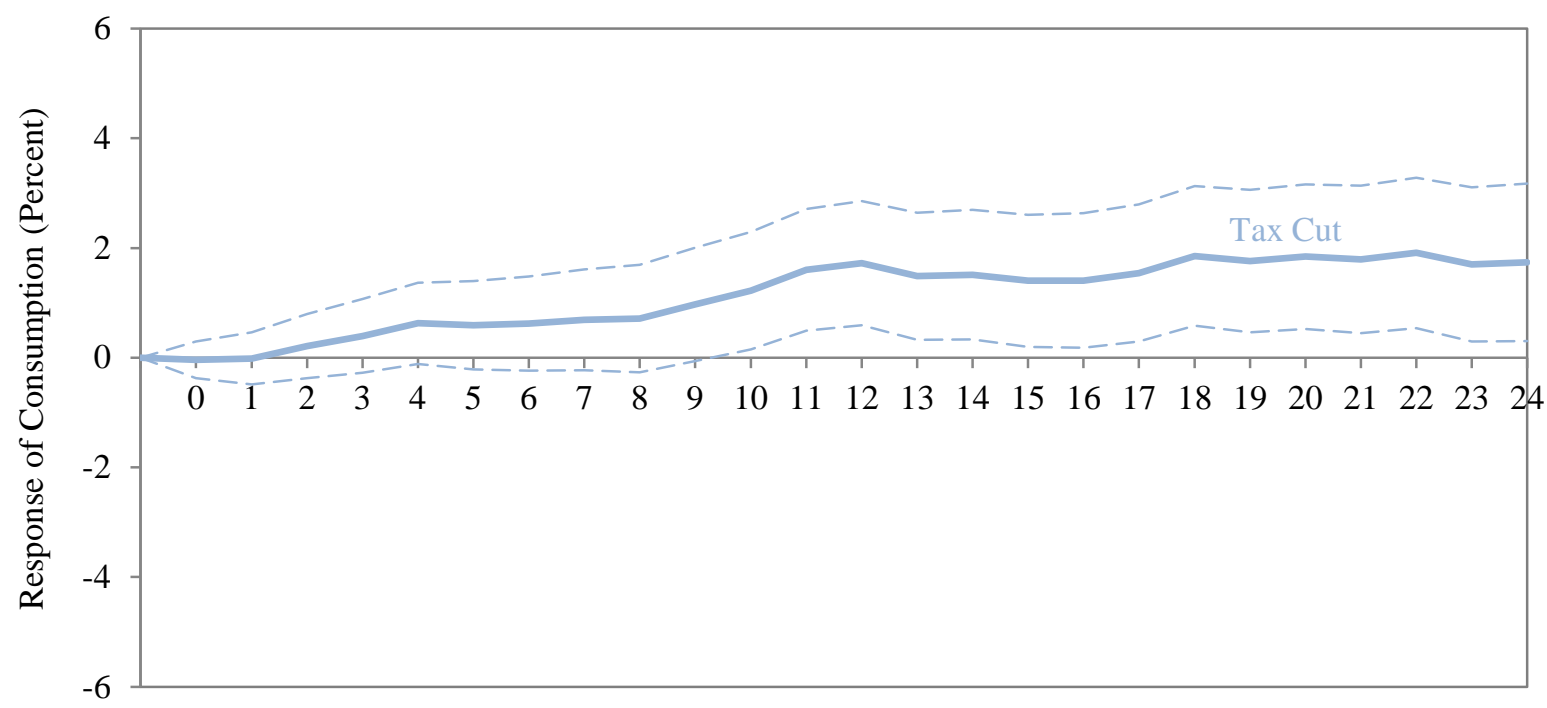

Months after the Increase

\section{b. Impact of a Permanent Benefit Increase and a Tax Cut}

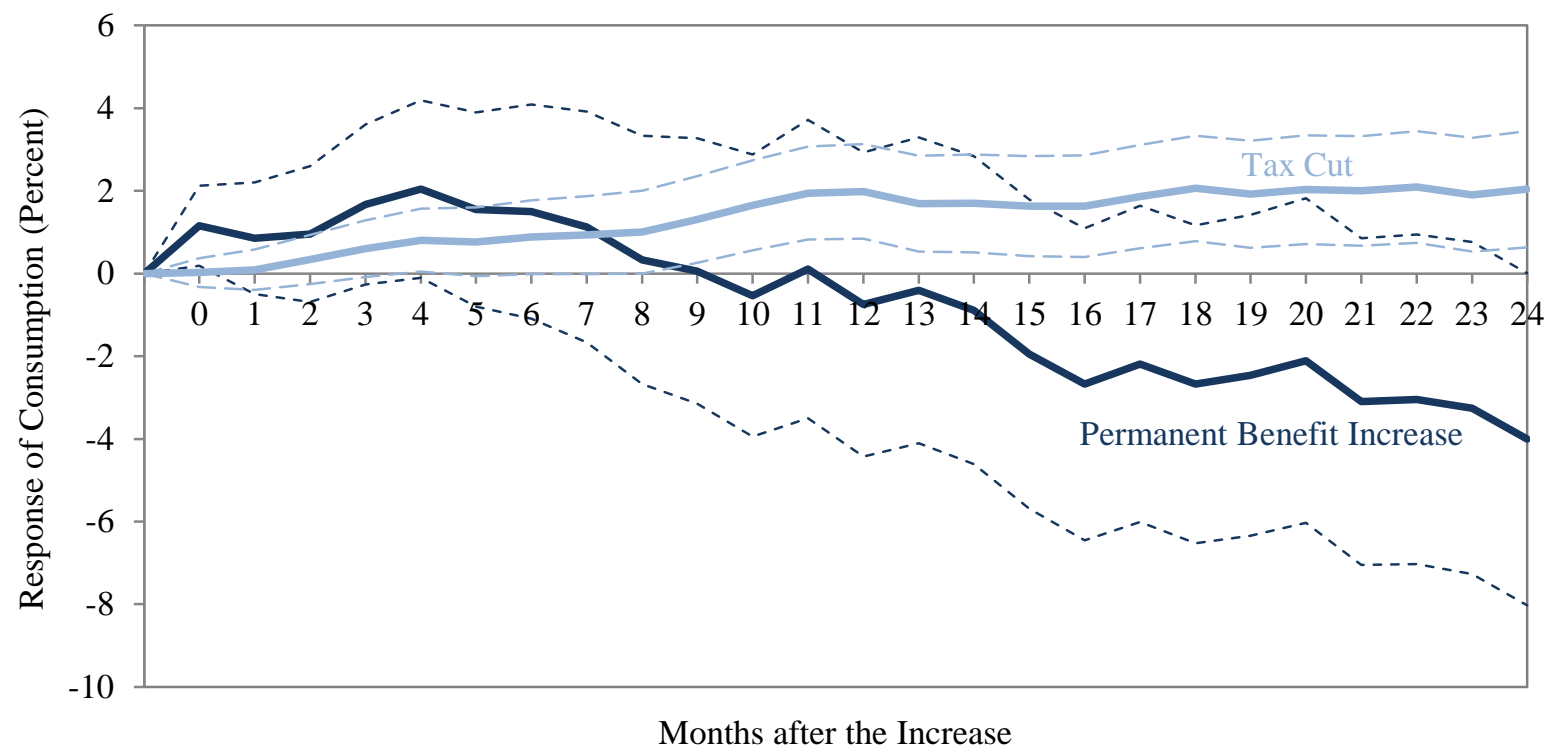

Notes: The results in panel (a) are from estimating equation (2) including the contemporaneous value and 12 lags of both permanent and temporary benefit increases, and including the contemporaneous value and 24 lags of the tax variable as additional controls. The results in panel (b) are from estimating equation (2) including the contemporaneous value and 24 lags of both permanent and temporary benefit increases, and the contemporaneous value and 24 lags of the tax variable. The sample period in panel (a) is 1952:1-1991:12; in panel (b) it is 1953:11991:12. The dashed lines show the two-standard-error confidence bands. 


\section{FIGURE B8}

Industrial Production Results for Tax Cuts Going out 24 Months

(Cumulative Impact of a Tax Cut of 1 Percent of Personal Income on Industrial Production)

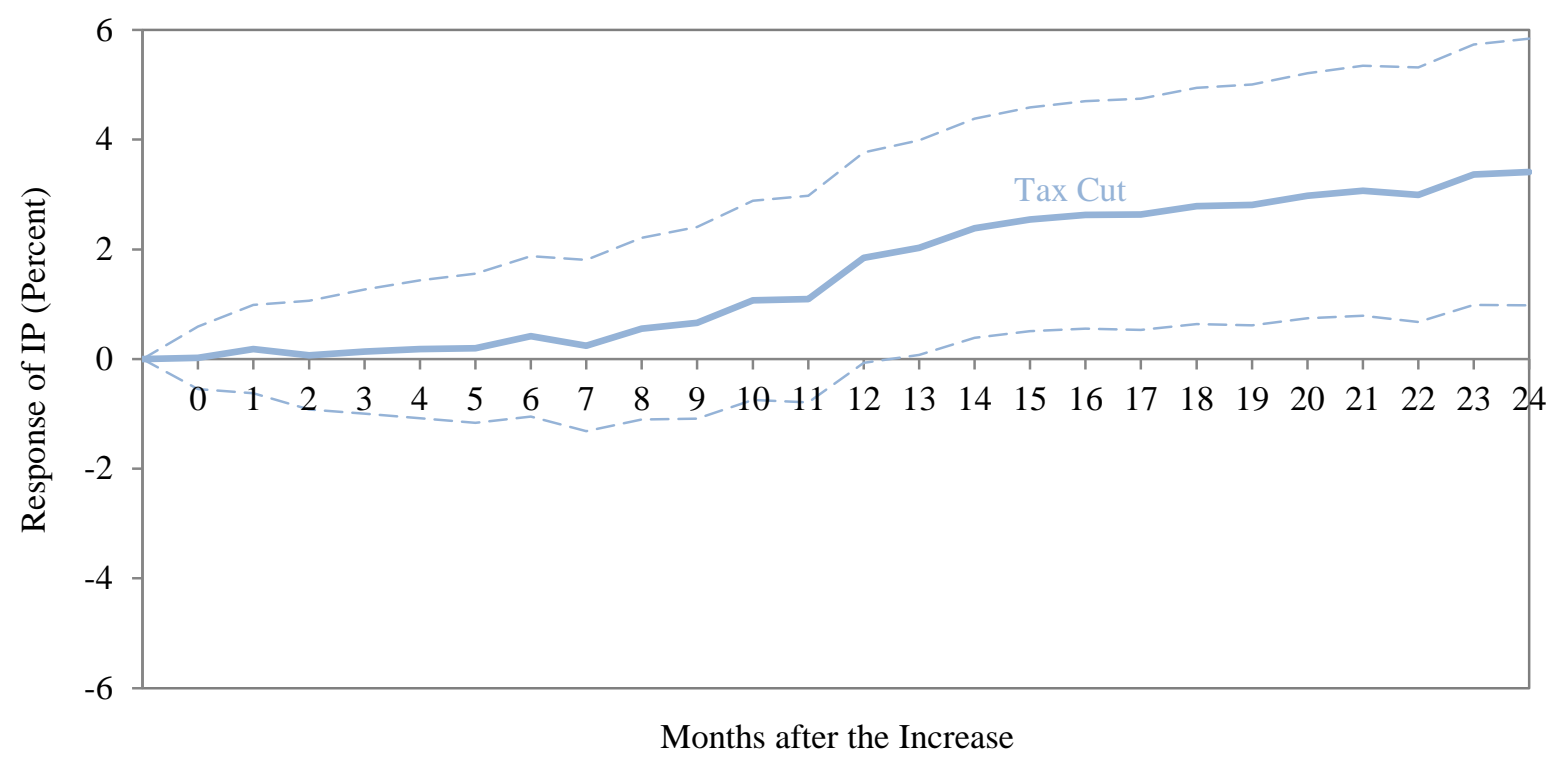

Notes: The figure shows the results from estimating equation (2) with the change in the logarithm of the index of industrial production as the dependent variable. The regression includes the contemporaneous value and 12 lags of both permanent and temporary benefit increases, and includes the contemporaneous value and 24 lags of the tax variable as additional controls. The sample period is 1952:1-1991:12. The dashed lines show the two-standarderror confidence bands. 


\section{FIGURE B9 \\ Consumption Results for Tax Cuts (Timing Adjusted to Reflect Withholding) \\ (Cumulative Impact of a Tax Cut of 1 Percent of Personal Income on Consumption)}

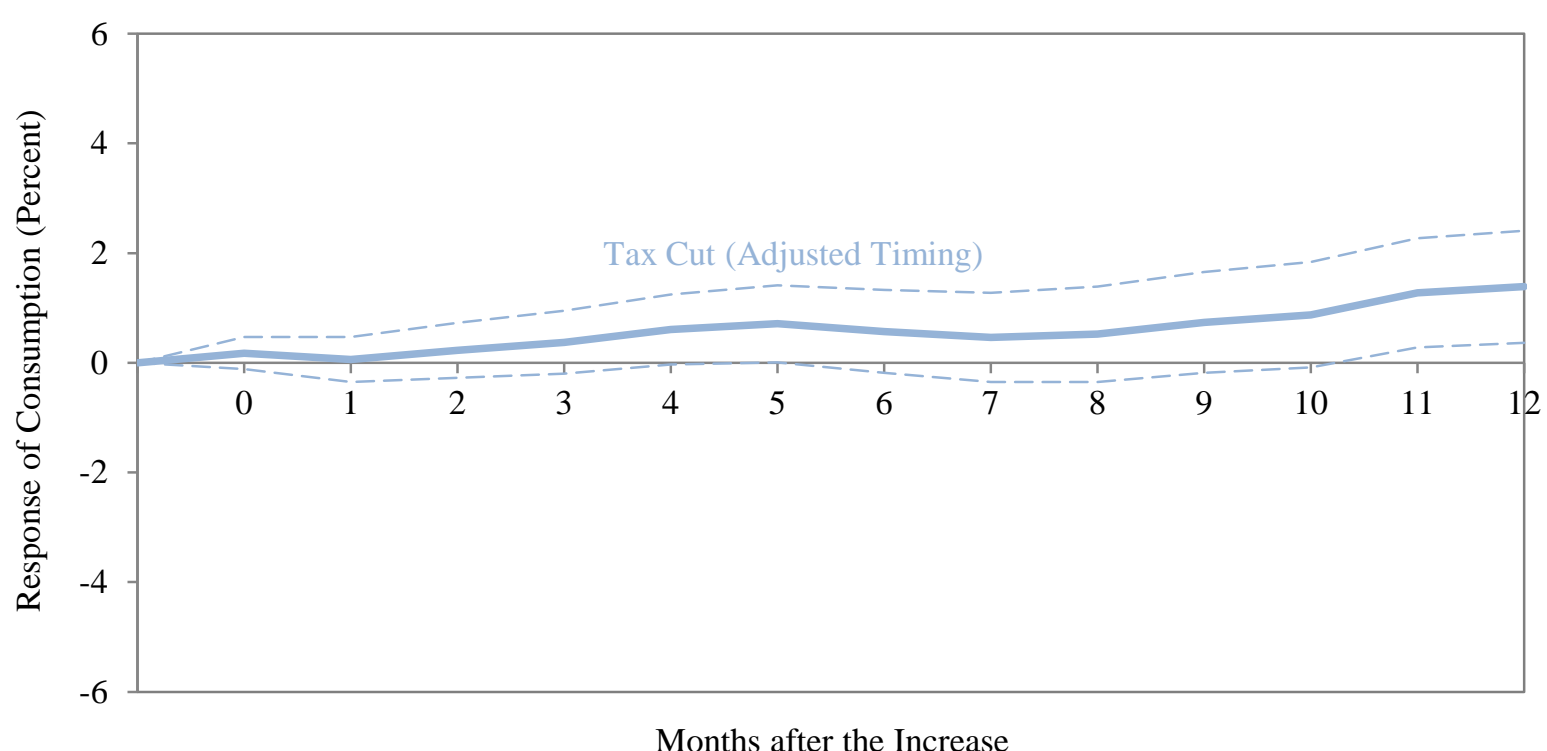

Notes: The figure shows the results from estimating equation (2) including the contemporaneous value and 12 lags of both permanent and temporary benefit increases, and including the contemporaneous value and 24 lags of the tax variable as additional controls. The tax variable used adjusts the timing of the 1964 and Reagan tax cuts to more closely reflect the change in withholding; see text for details. The sample period is 1952:1-1991:12. The dashed lines show the two-standard-error confidence bands. 


\section{FIGURE B10}

\section{Baseline Funds Rate Results for the Post-1959 Sample}

(Cumulative Impact of a Benefit Increase of 1 Percent of Personal Income on the Funds Rate)

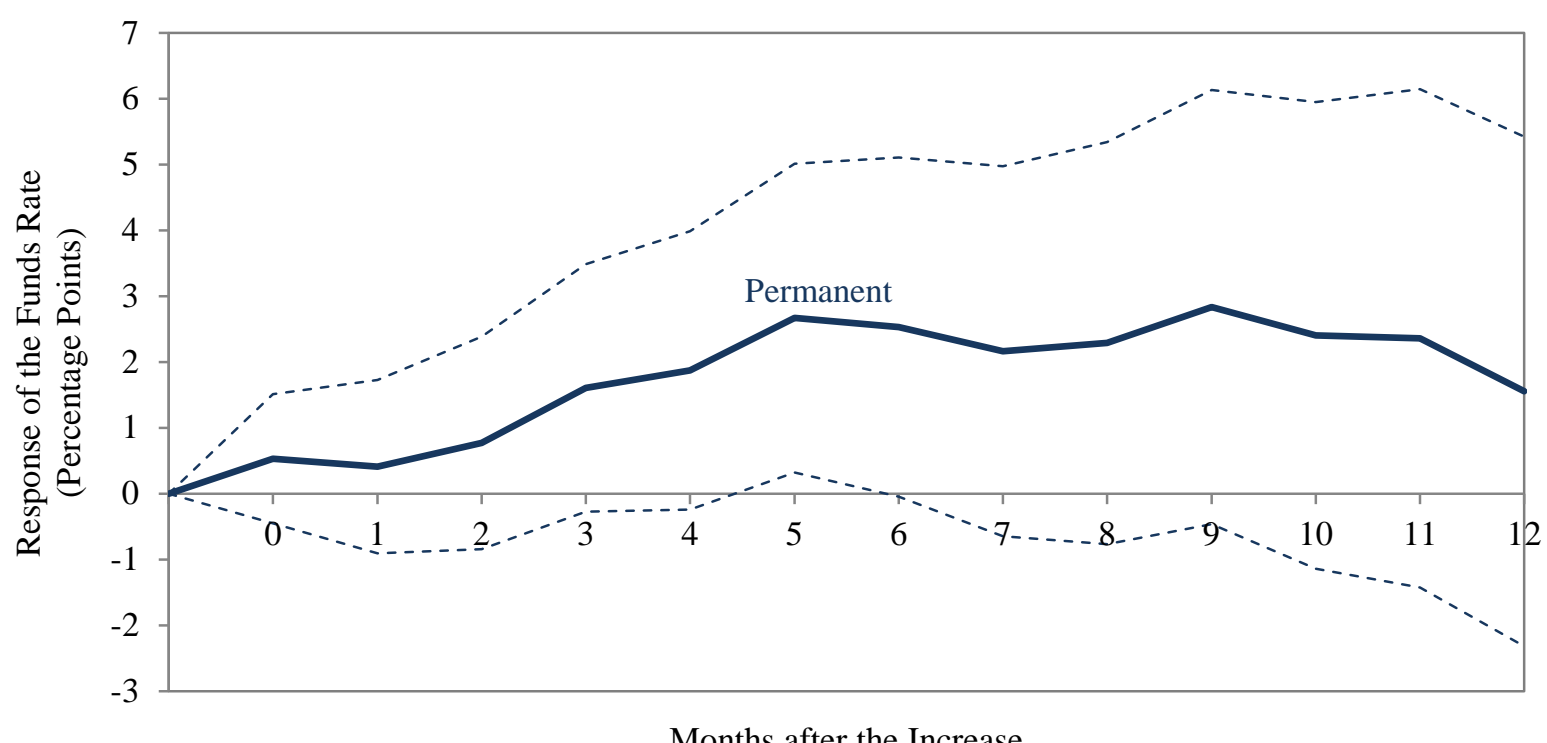

Notes: The figure shows the results from estimating equation (3) over the sample period 1959:2-1991:12, including the contemporaneous value and 12 lags of both permanent and temporary benefit increases. The dashed lines show the two-standard-error confidence bands. 


\section{FIGURE B11}

Baseline Consumption Results for the Pre-Volcker Sample Period

(Cumulative Impact of a Benefit Increase of 1 Percent of Personal Income on Consumption)

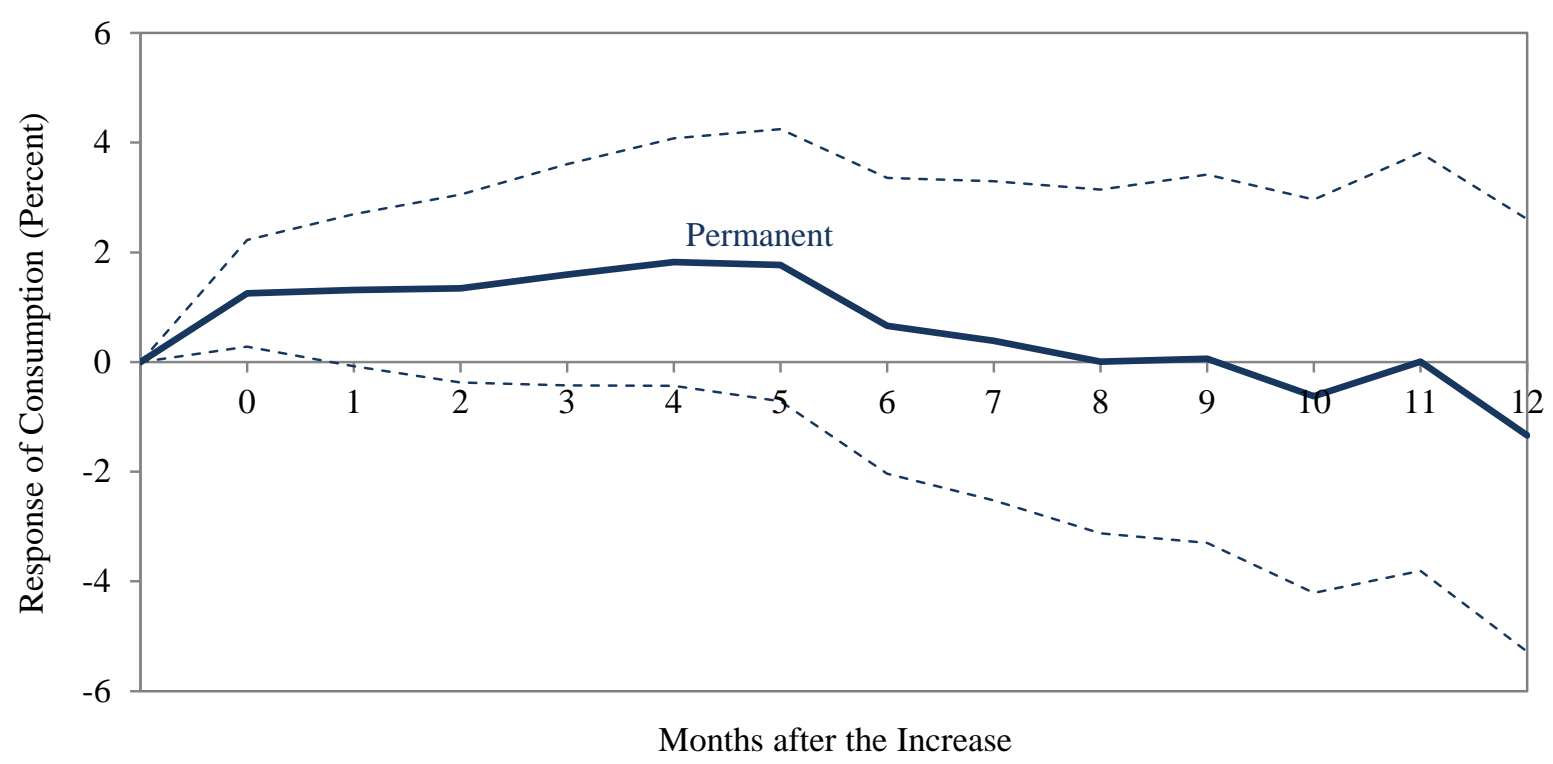

Notes: The figure shows the results from estimating equation (2) over the sample period 1952:1-1979:9, including the contemporaneous value and 12 lags of both permanent and temporary benefit increases. The dashed lines show the two-standard-error confidence bands. 


\section{FIGURE B12}

Baseline Federal Funds Rates Results for Alternative Sample Periods

(Cumulative Impact of a Benefit Increase of 1 Percent of Personal Income on the Funds Rate)

a. 1952:1-1974:12

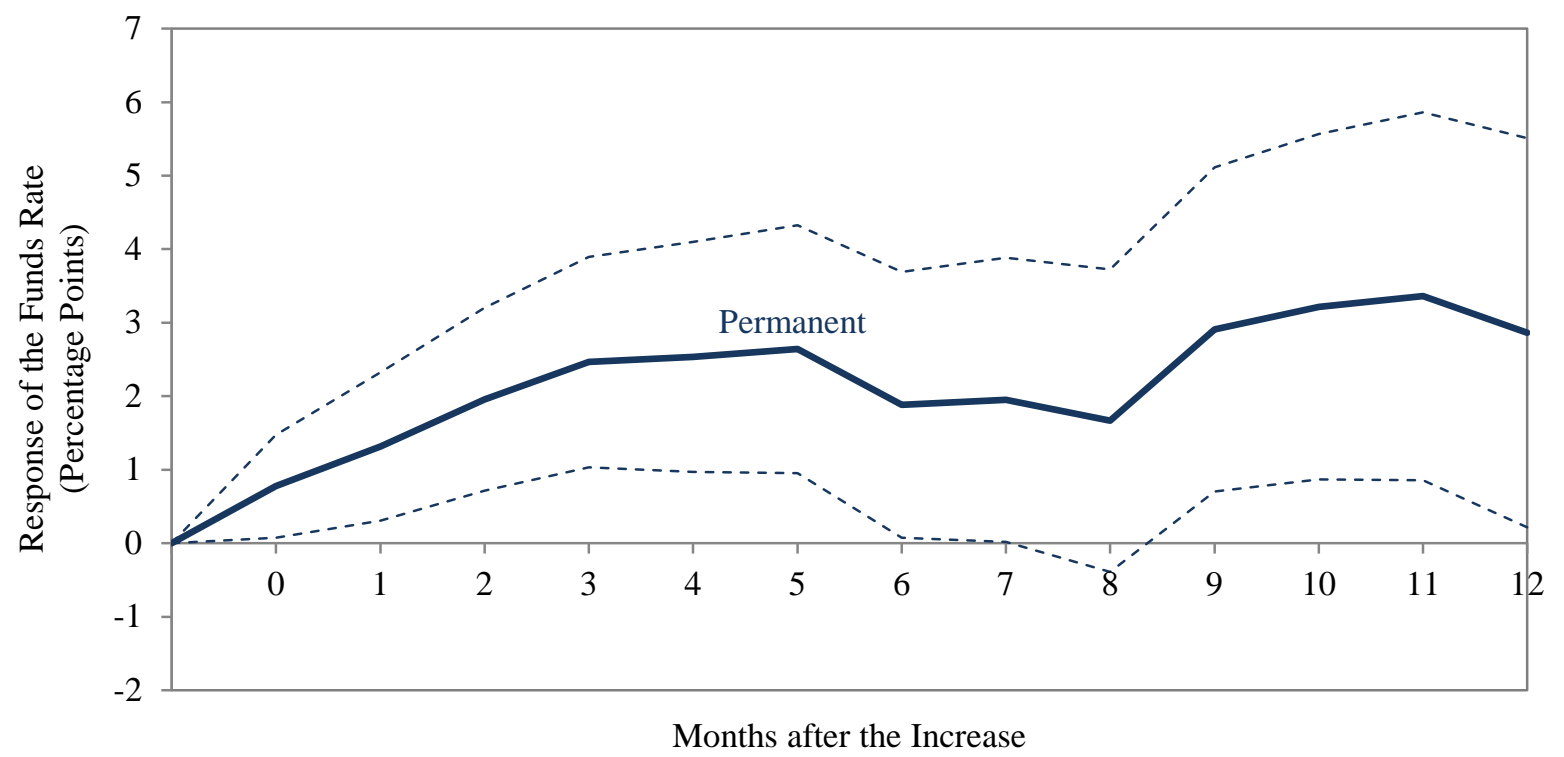

b. 1952:1-1991:12

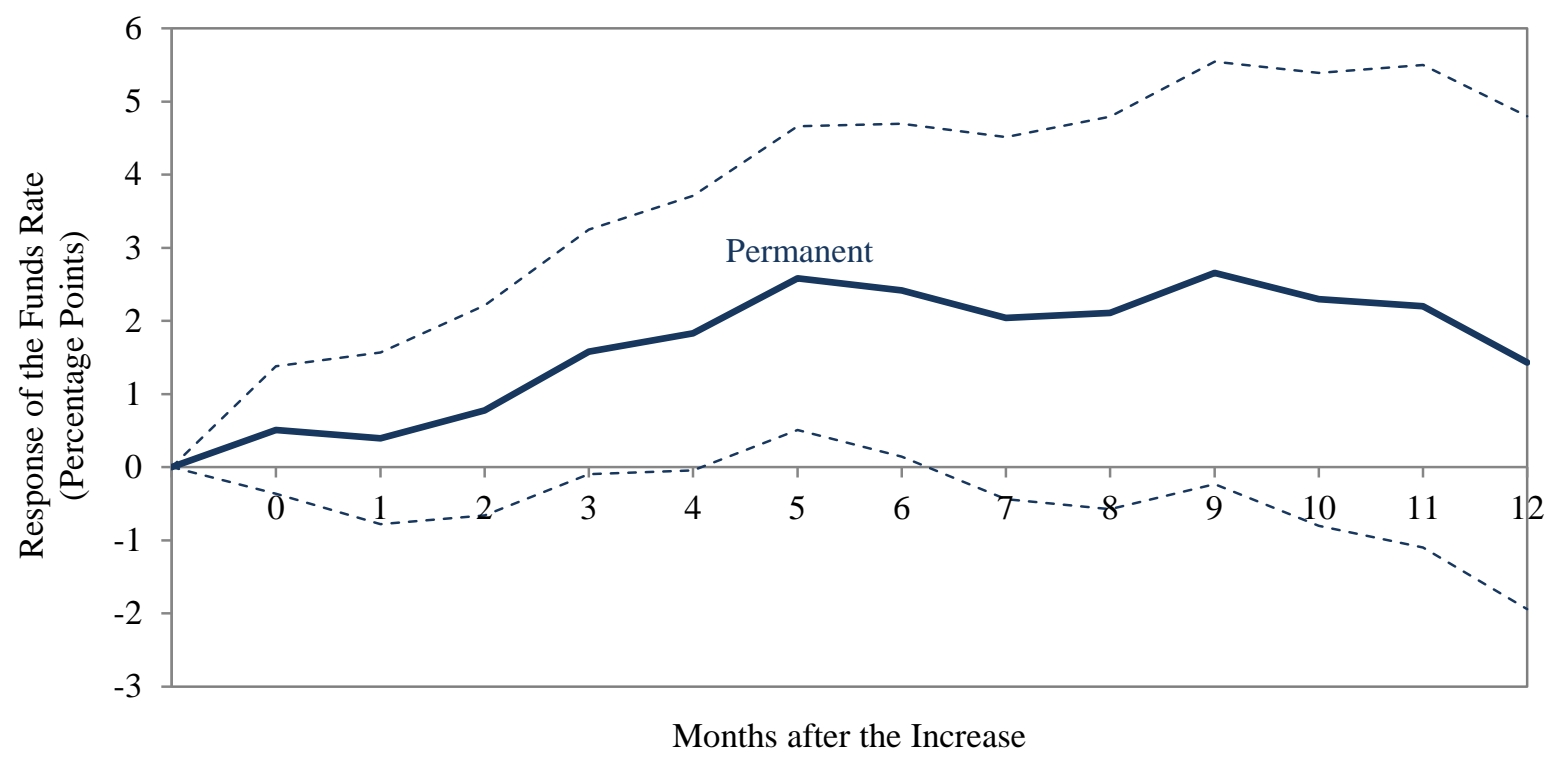


FIGURE B12 (Continued)

Baseline Federal Funds Rates Results for Alternative Sample Periods

(Cumulative Impact of a Benefit Increase of 1 Percent of Personal Income on the Funds Rate)

c. 1952:1-1979:9, Excluding the Permanent Benefit Increase in 1972:10

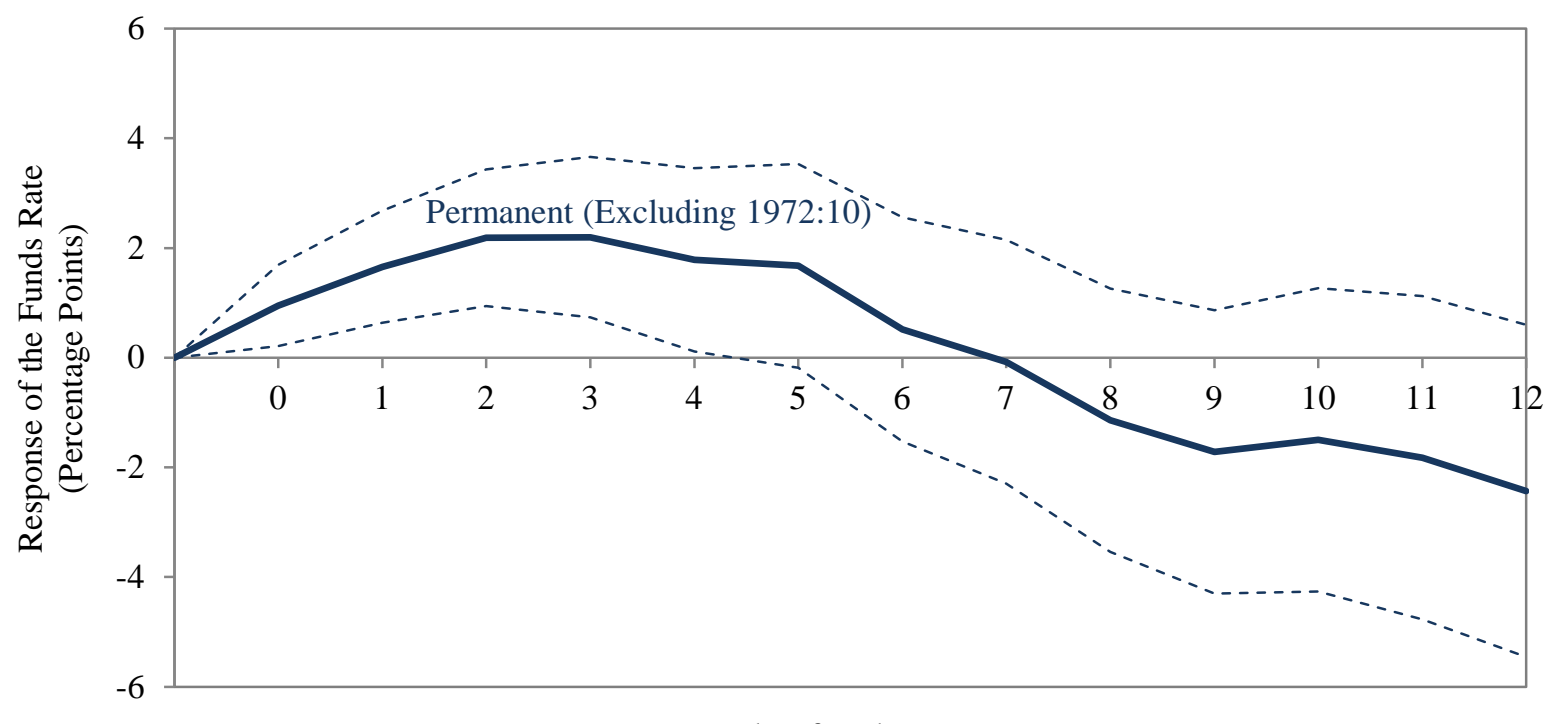

Months after the Increase

Notes: The figures show the results from estimating equation (3) over various alternative sample periods, including the contemporaneous value and 12 lags of both permanent and temporary benefit increases. The dashed lines show the two-standard-error confidence bands. 


\section{FIGURE B13}

Federal Funds Rate Results Including Various Control Variables

(Cumulative Impact of a Benefit Increase of 1 Percent of Personal Income on the Funds Rate)

a. Controlling for the Contemporaneous Value and 12 Lags of Oil Price Inflation

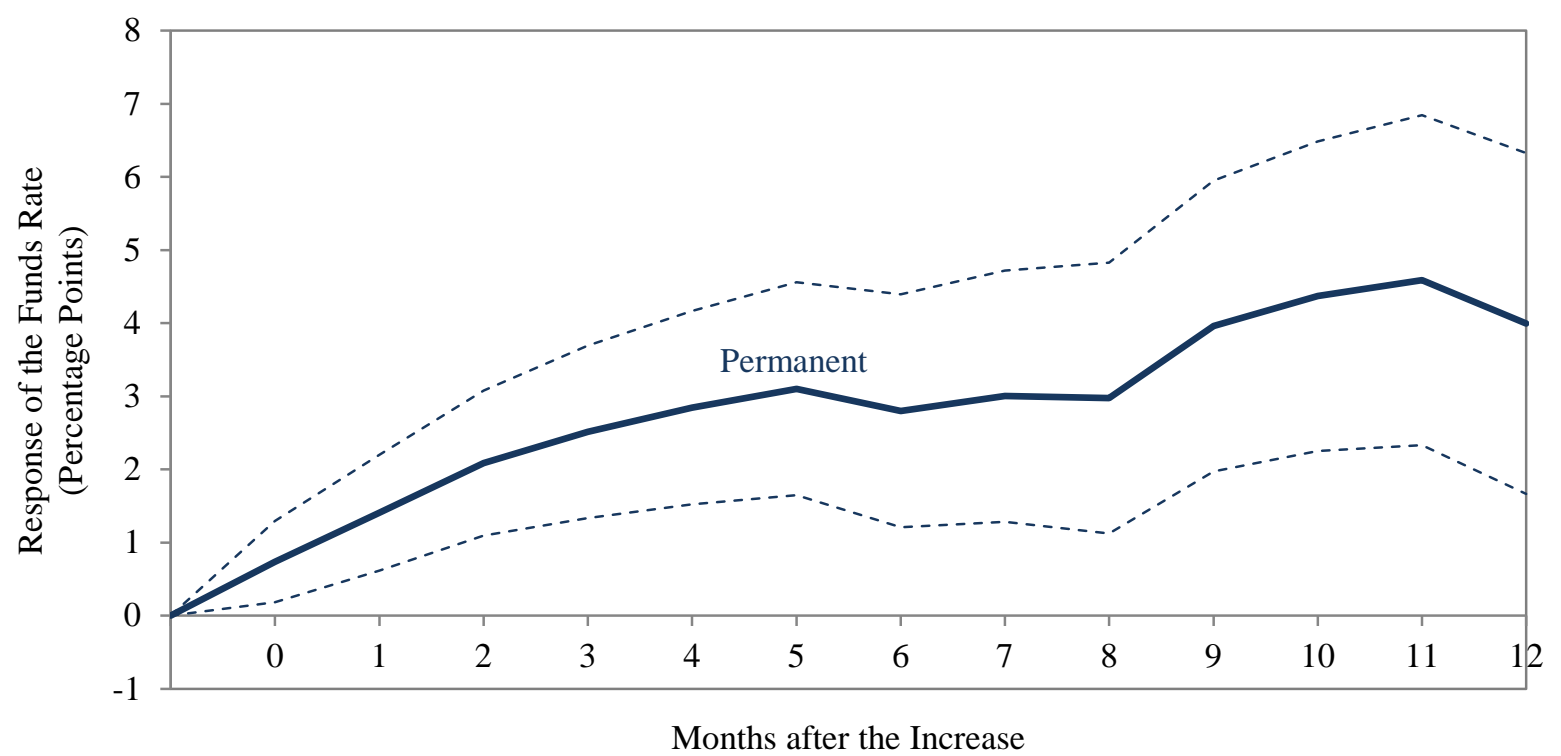

b. Controlling for the Contemporaneous Value and 12 Lags of Monetary Policy Shocks

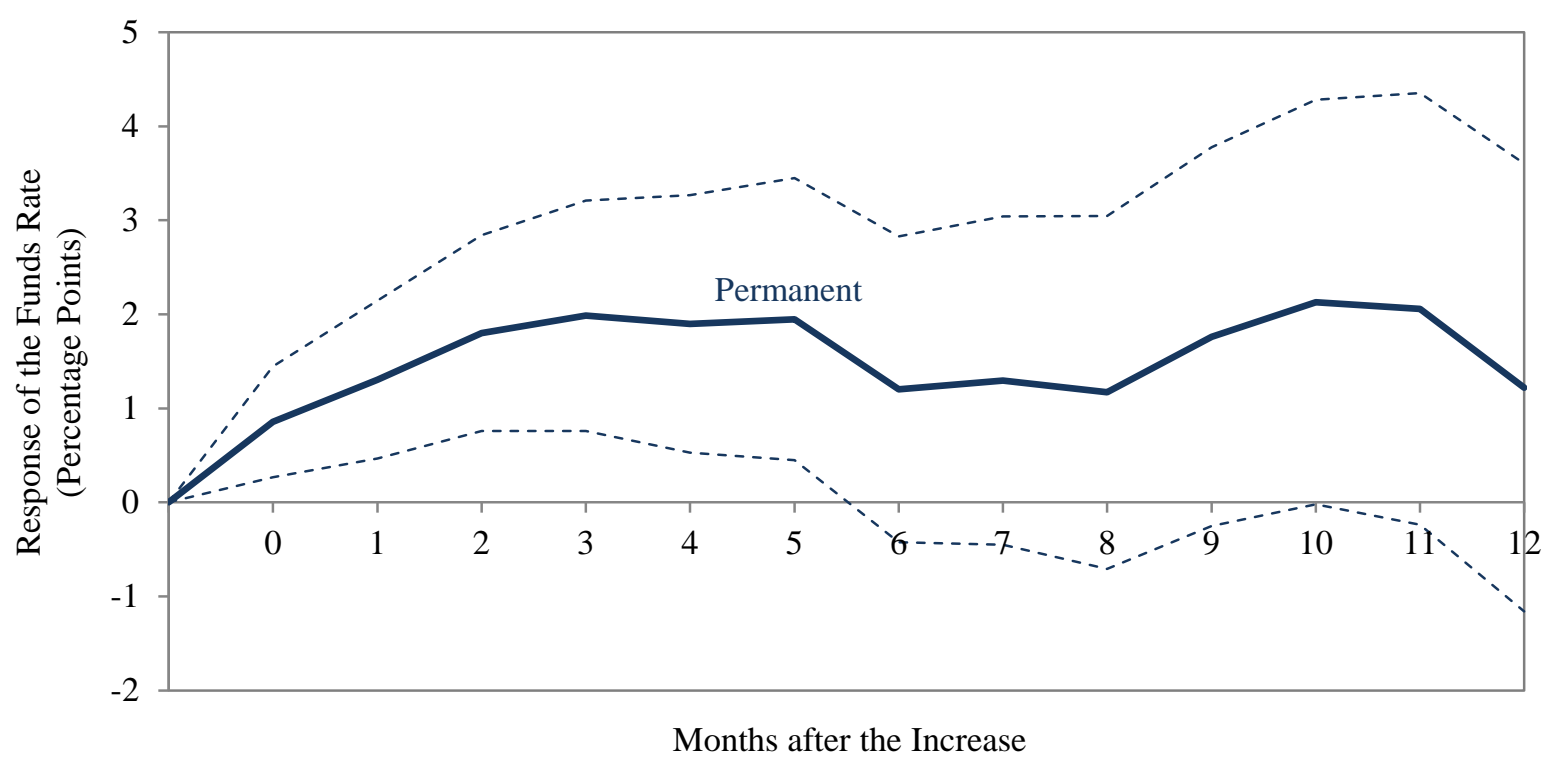


Figure B13 (Continued)

Federal Funds Rate Results Including Various Control Variables

(Cumulative Impact of a Benefit Increase of 1 Percent of Personal Income on the Funds Rate)

\section{c. Controlling for the Contemporaneous Value and 24 Lags of Monetary Policy Shocks}

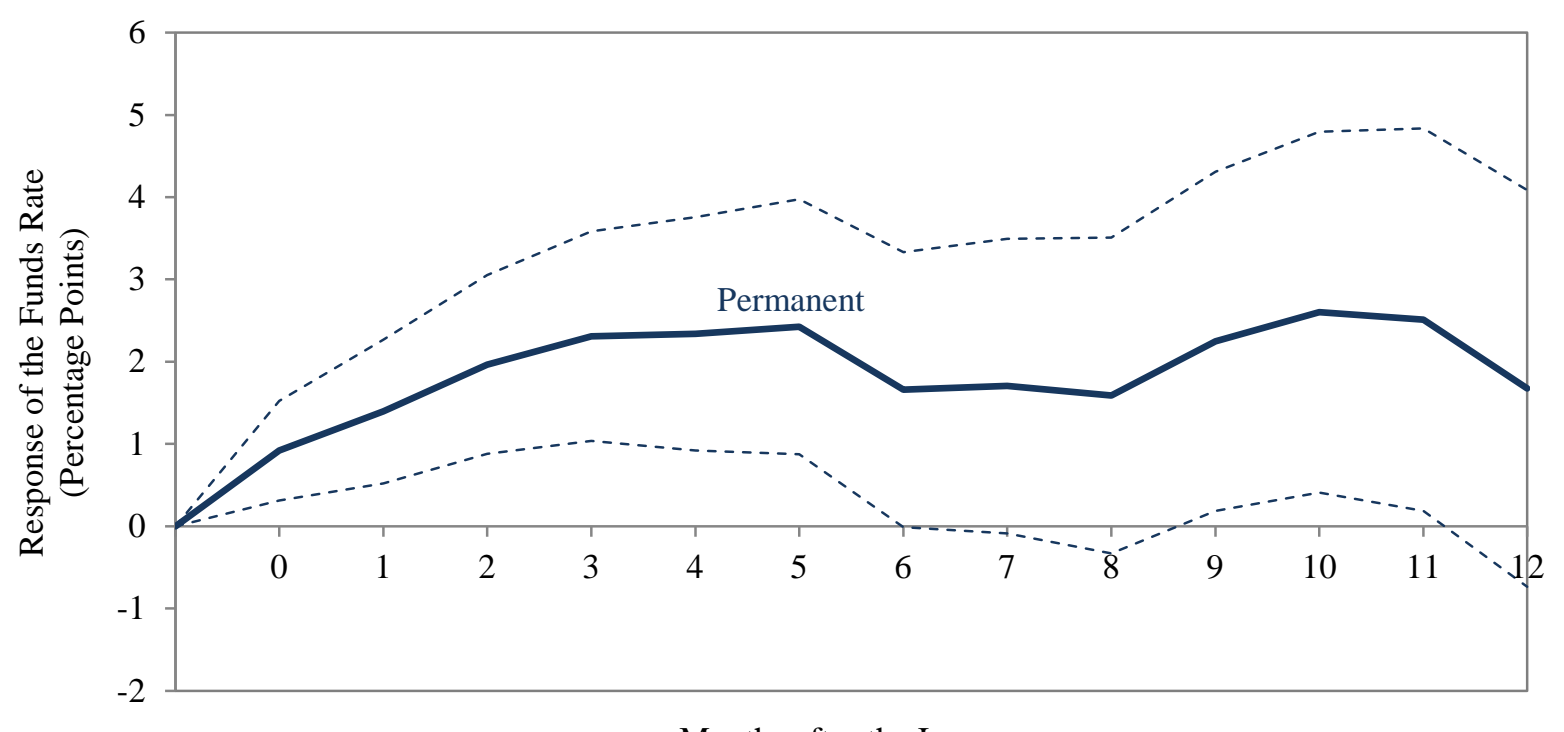

Months after the Increase

Notes: The figures show the results from estimating equation (3) over the sample period 1952:1-1979:9, including the contemporaneous value and 12 lags of both permanent and temporary benefit increases, and including various additional control variables. Panel (a) includes the contemporaneous value and 12 lags of the change in the logarithm of oil prices; panel (b) includes the contemporaneous value and 12 lags of the Romer and Romer dummy variable for shifts to contractionary monetary policy; and panel (c) includes the contemporaneous value and 24 lags of the Romer and Romer dummy. See the text for the details and the sources of the control variables. The dashed lines in the figure show the two-standard-error confidence bands. 


\section{FIGURE B14}

Baseline Federal Funds Rate Results Including Three Leads

(Regression Coefficients and Cumulative Impact of a Benefit Increase of 1 Percent of Personal Income)

\section{a. Regression Coefficients for Permanent Benefit Increases}

\begin{tabular}{cccc}
$\begin{array}{c}\text { Lag of the Permanent } \\
\text { Benefits Variable }\end{array}$ & $\begin{array}{c}\text { Coefficient } \\
\text { Estimate }\end{array}$ & Standard Error & $t$-Statistic \\
\hline-3 & 0.06 & 0.30 & 0.20 \\
-2 & 0.29 & 0.30 & 0.97 \\
-1 & 0.11 & 0.30 & 0.35 \\
0 & 0.85 & 0.30 & 2.84 \\
1 & 0.58 & 0.29 & 2.01 \\
2 & 0.63 & 0.29 & 2.21 \\
3 & 0.38 & 0.31 & 1.25 \\
4 & 0.05 & 0.31 & 0.17 \\
5 & 0.13 & 0.31 & 0.42 \\
6 & -0.79 & 0.31 & -2.58 \\
7 & -0.01 & 0.31 & -0.03 \\
8 & -0.24 & 0.31 & -0.79 \\
9 & 0.57 & 0.32 & 1.79 \\
10 & 0.27 & 0.32 & 0.85 \\
11 & -0.04 & 0.32 & -0.14 \\
12 & -0.65 & 0.32 & -2.04 \\
\hline
\end{tabular}

b. Cumulative Impact on the Funds Rate

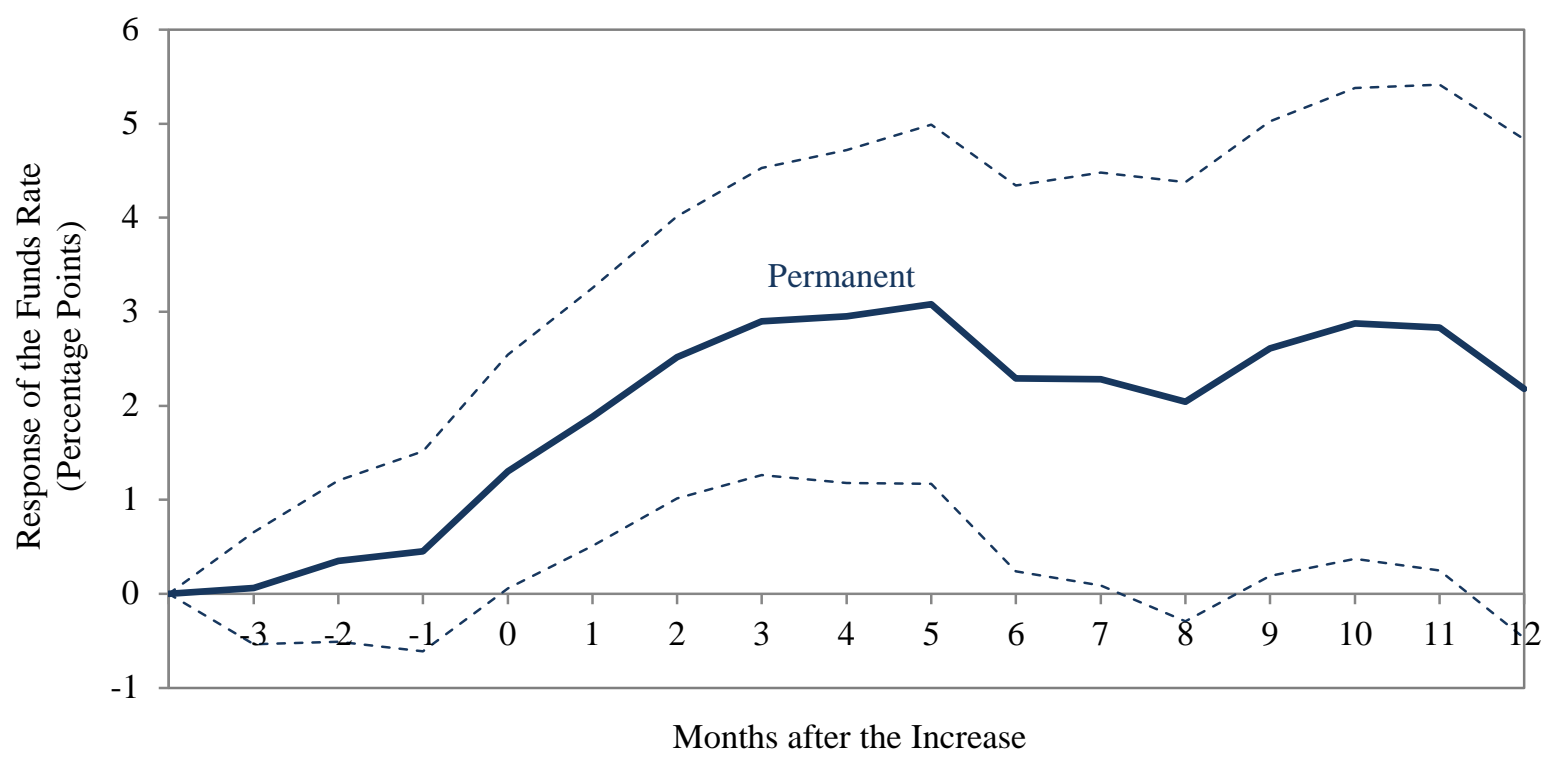

Notes: The regression coefficients and the figure show the results from estimating equation (3) over the sample period 1952:1-1979:9, including 3 leads, the contemporaneous value, and 12 lags of both permanent and temporary benefit increases. The dashed lines show the two-standard-error confidence bands. 


\section{FIGURE B15}

Consumption Results for Permanent Benefit Increases from a Five-Variable VAR

(Cumulative Impact of a Benefit Increase of 1 Percent of Personal Income on Consumption)

\section{a. Pre-Volcker Sample (1952:1-1979:9)}

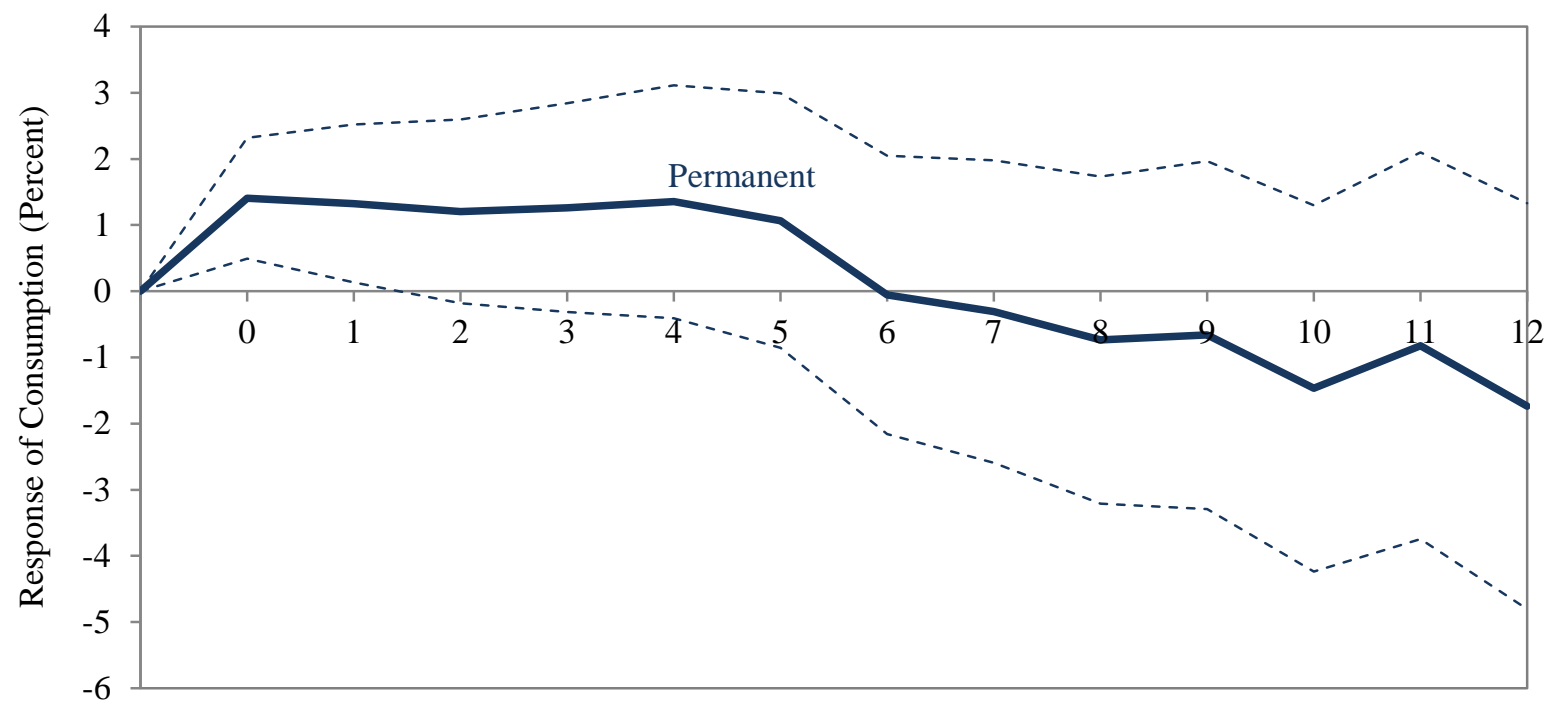

Months after the Increase

\section{b. Full Sample (1952:1-1991:12)}

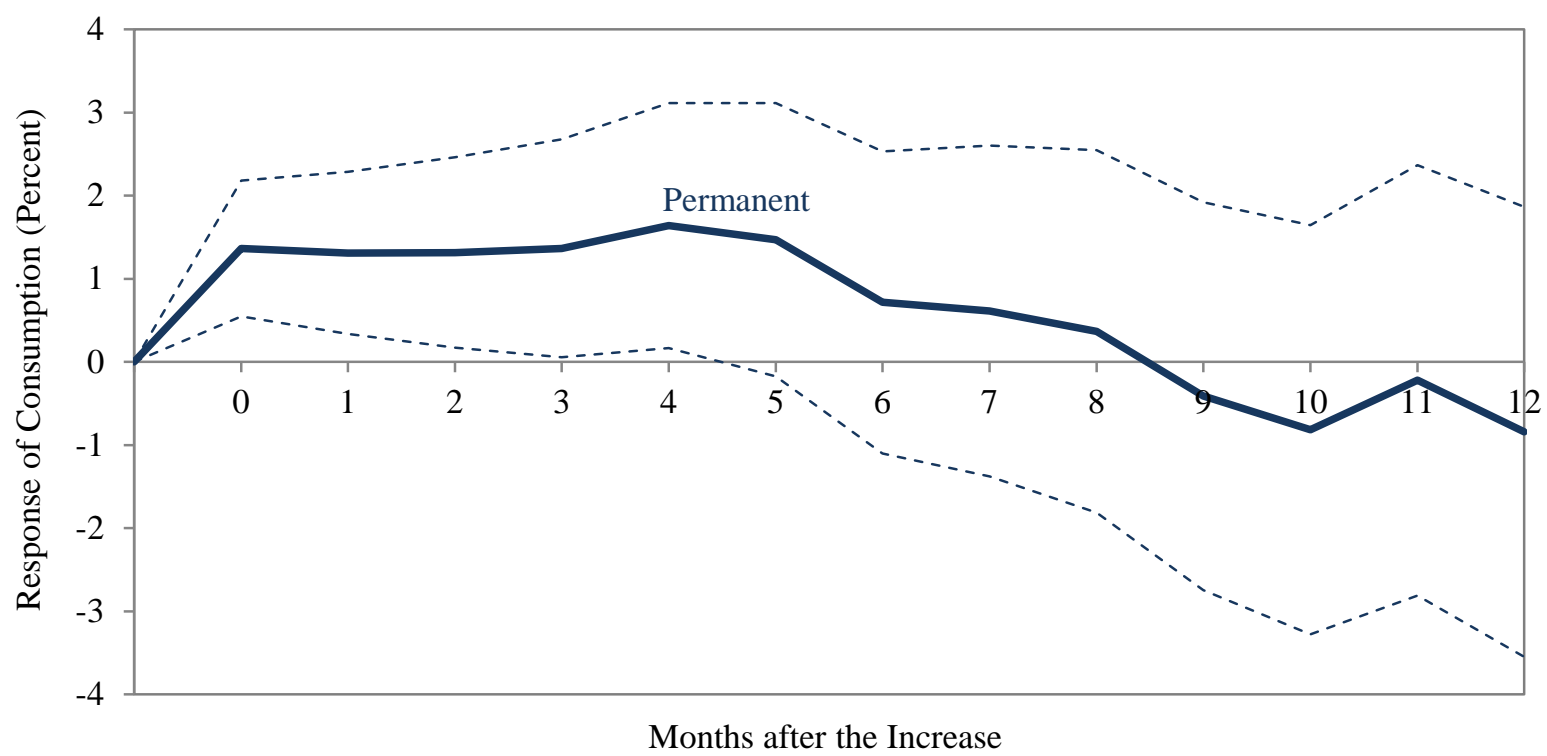

Notes: The figure shows the results from estimating a vector autoregression including five variables (permanent benefit increases, temporary benefit increases, the logarithm of prices, the logarithm of personal consumption expenditures, and the federal funds rate) over the pre-Volcker (1952:1-1979:9) and full (1952:1-1991:12) sample periods. The dashed lines show the two-standard-error confidence bands. 


\section{FIGURE B16}

Federal Funds Rate Results for Benefit Increases with and without Tax Changes (Cumulative Impact of a Benefit Increase of 1 Percent of Personal Income on the Funds Rate)

\section{a. Permanent Benefit Increase}

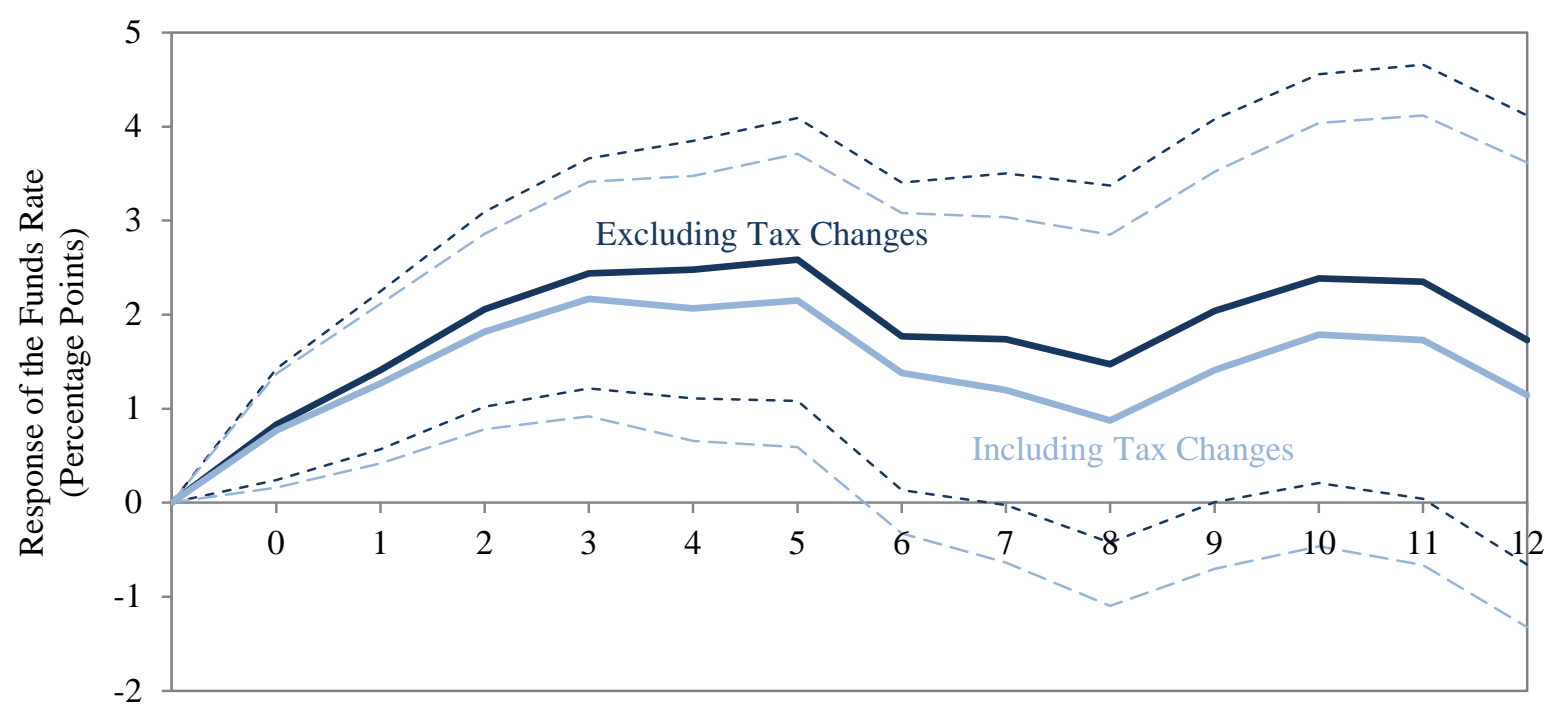

Months after the Increase

\section{b. Temporary Benefit Increase}

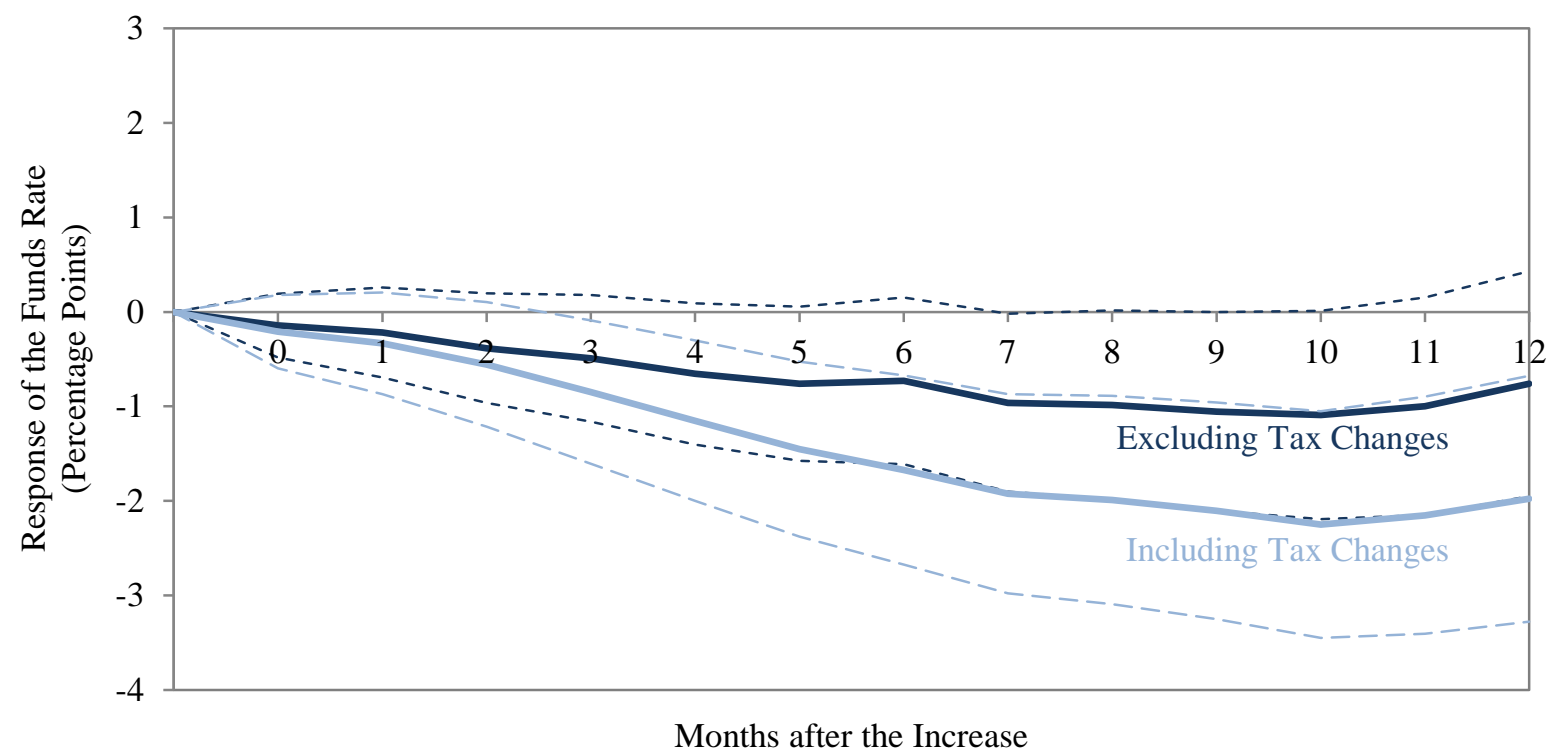

Notes: The dark blue line in each panel shows the baseline results from estimating equation (3) including the contemporaneous value and 12 lags of both permanent and temporary benefit increases. The light blue line in each panel shows the results from estimating equation (3) including the contemporaneous value and 12 lags of both permanent and temporary benefit increases, and including the contemporaneous value and 24 lags of the tax variable as additional controls. The sample period is 1952:1-1979:9. The dashed lines show the two-standard-error confidence bands. 


\section{FIGURE B17}

\section{Federal Funds Rate Results Going out 24 Months}

(Cumulative Impact of a Benefit Increase and a Tax Cut of 1 Percent of Personal Income on the Funds Rate)

\section{a. Impact of a Tax Cut}

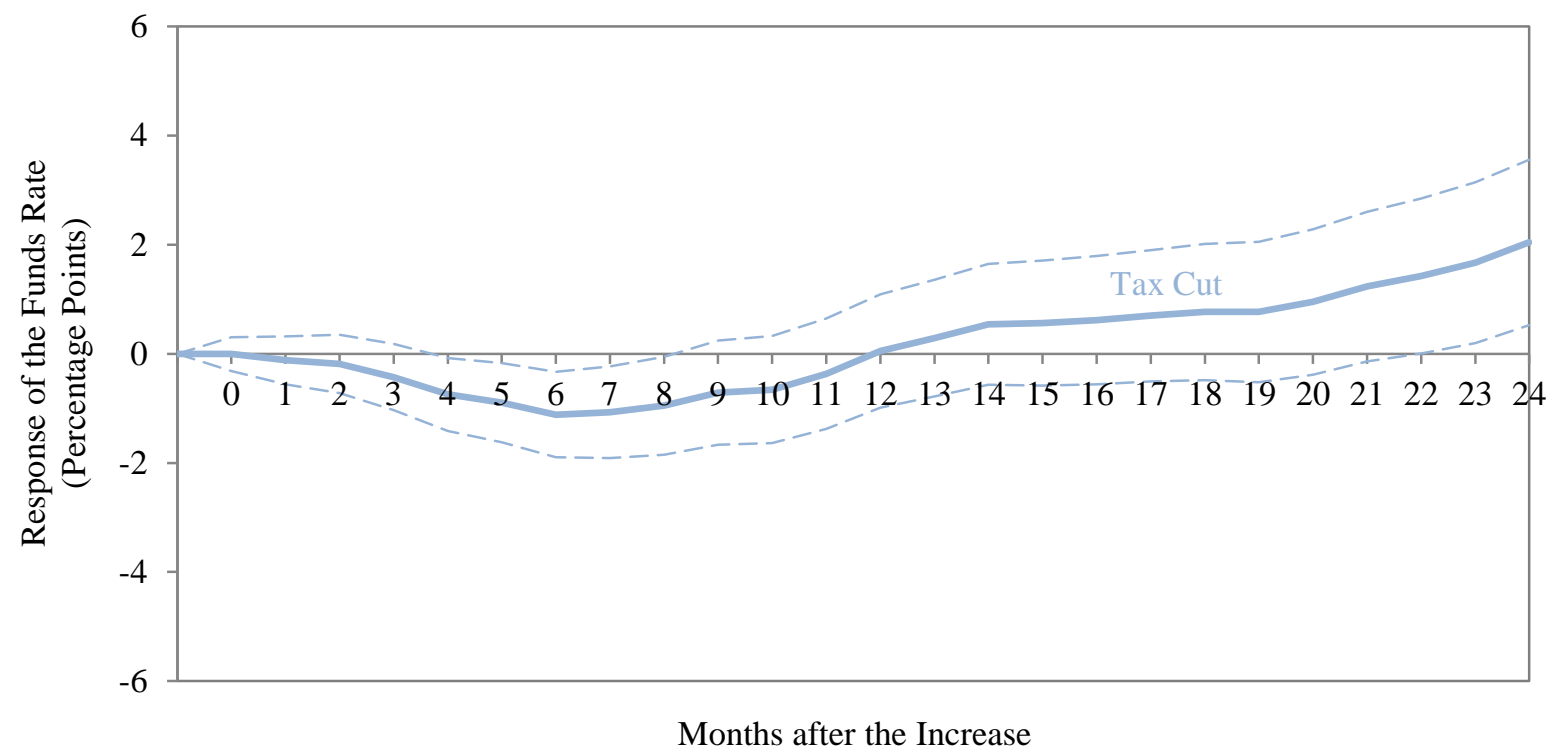

b. Impact of a Permanent Benefit Increase and a Tax Cut

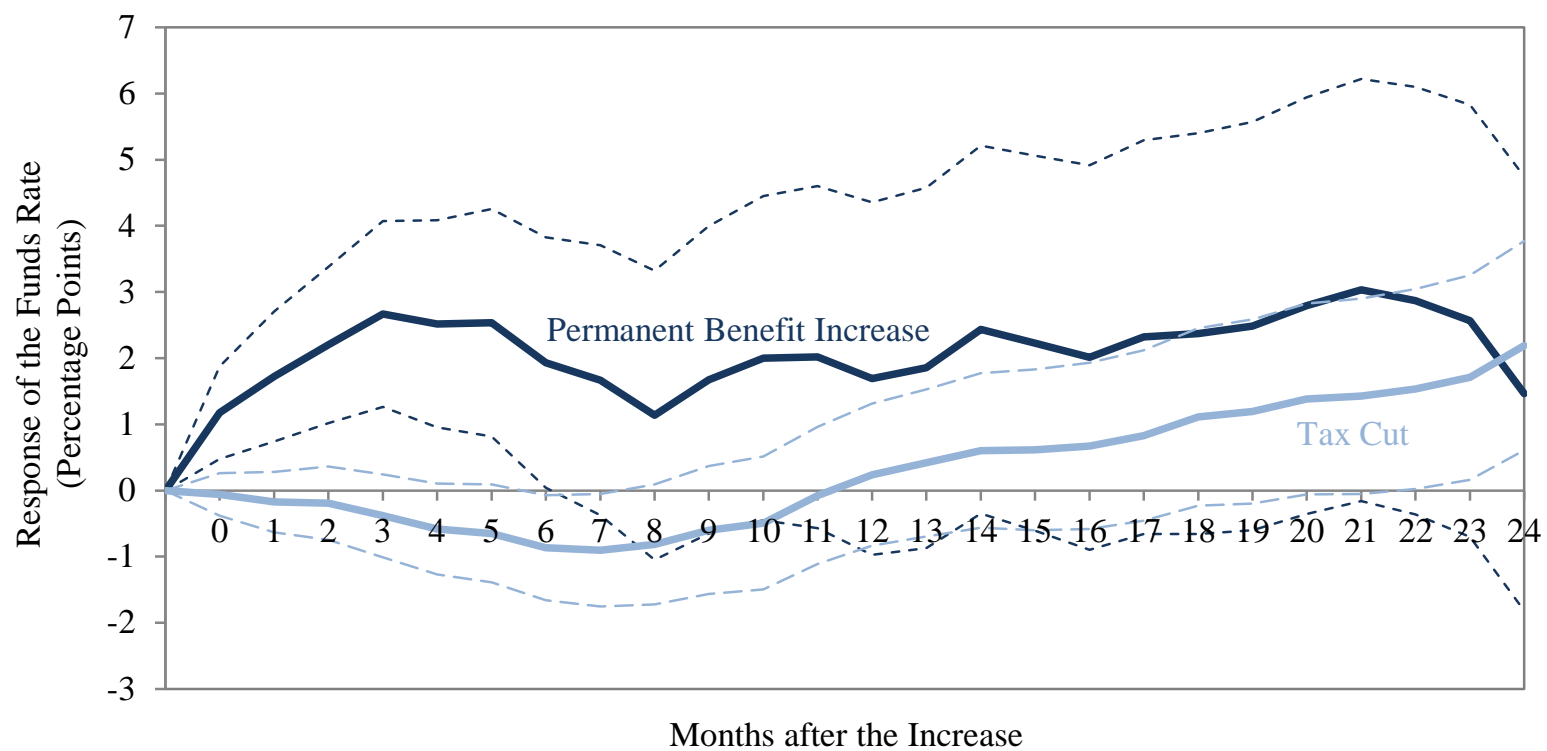

Notes: The results in panel (a) are from estimating equation (3) including the contemporaneous value and 12 lags of both permanent and temporary benefit increases, and including the contemporaneous value and 24 lags of the tax variable as additional controls. The results in panel (b) are from estimating equation (3) including the contemporaneous value and 24 lags of both permanent and temporary benefit increases, and the contemporaneous value and 24 lags of the tax variable. In panel (a), the sample period is 1952:1-1979:9; in panel (b) it is 1953:11979:9. The dashed lines show the two-standard-error confidence bands. 


\section{FIGURE B18}

Federal Funds Rate Results for Benefit Increases and Tax Cuts from a Six-Variable VAR

(Cumulative Impact of a Benefit Increase and a Tax Cut of 1 Percent of Personal Income on the Funds Rate)

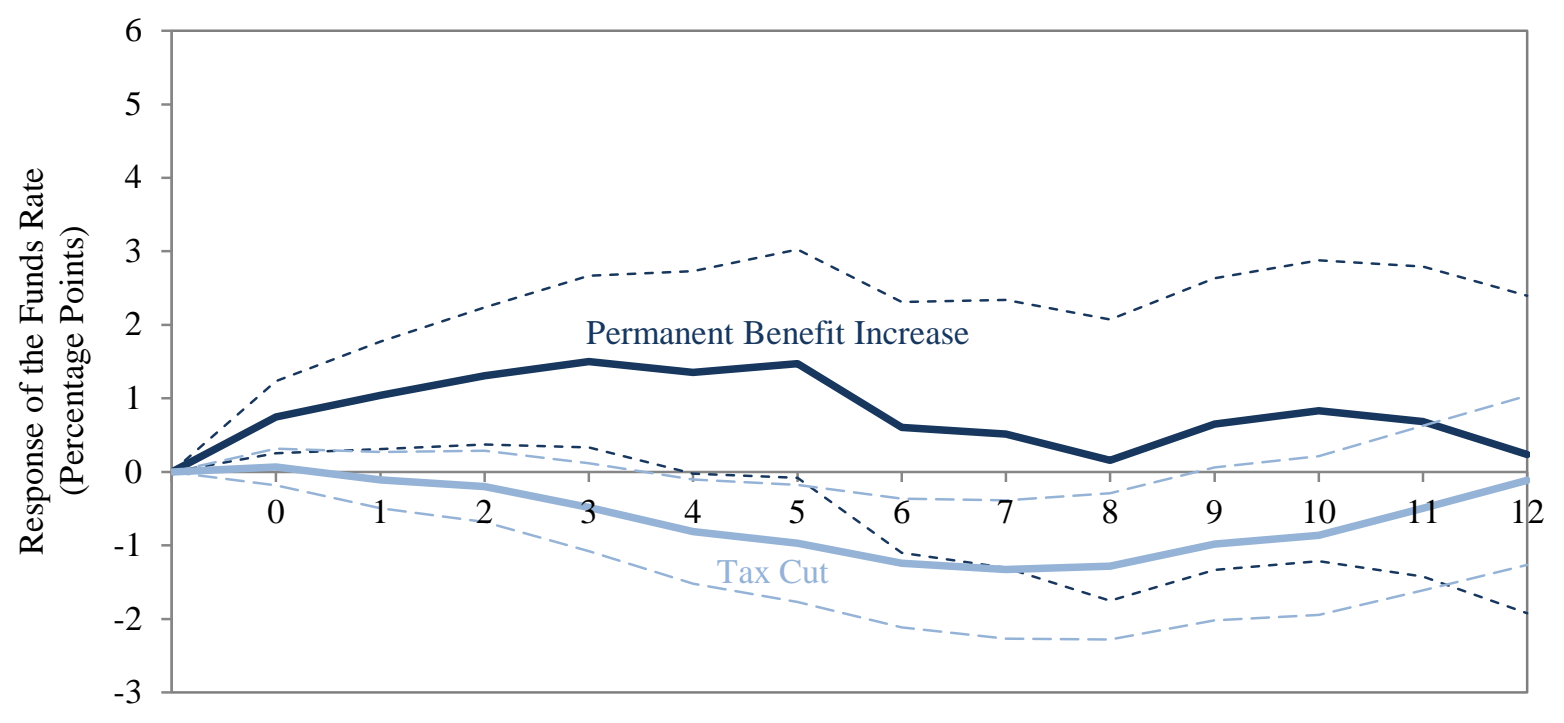

Months after the Increase

Notes: The figure shows the results from estimating a vector autoregression including six variables (permanent benefit increases, temporary benefit increases, tax changes, the logarithm of prices, the logarithm of personal consumption expenditures, and the federal funds rate) over the sample period 1952:1-1979:9. The dashed lines show the two-standard-error confidence bands. 